مقايسه زىتوده و اندوخته كربن روى زمينى، لاشريزه و خاى در تودههاى جنخلى سالم و دجّار زوال بلوط ايرانى (Quercus brantii Lindl) در استان جهارمحالوبختيارى

يعقوب ايرانمنش "“، مهدى يورهاشمى'، حسن جهانبازى' و محمود طالبى

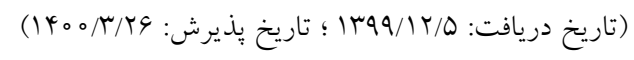

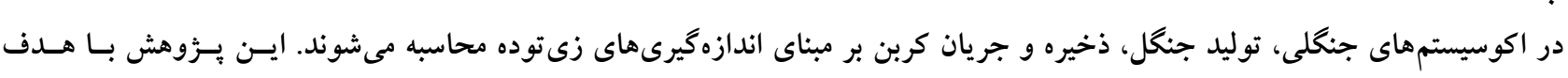

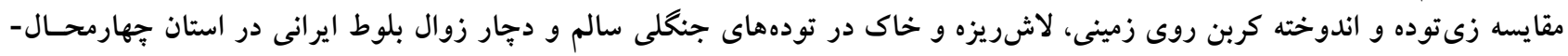

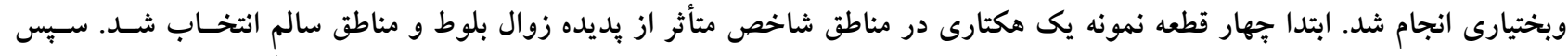

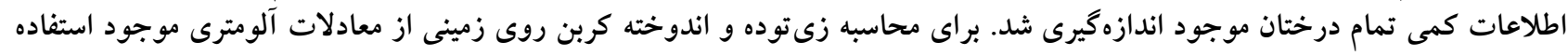

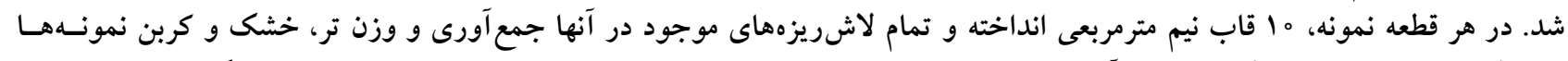

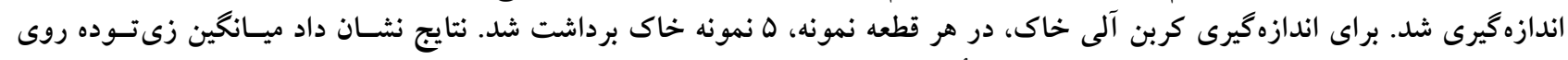

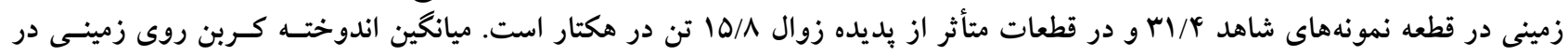

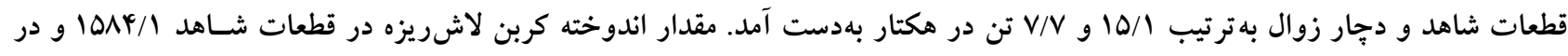

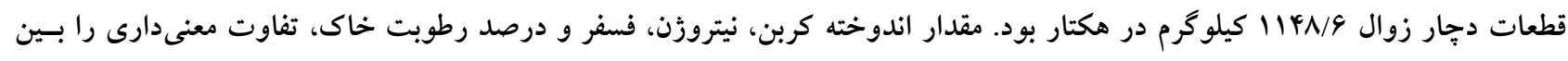

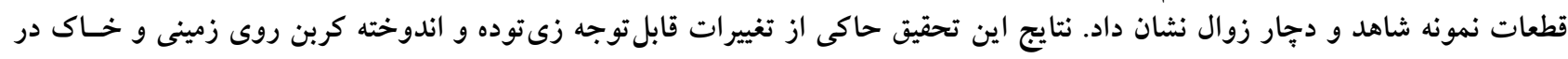

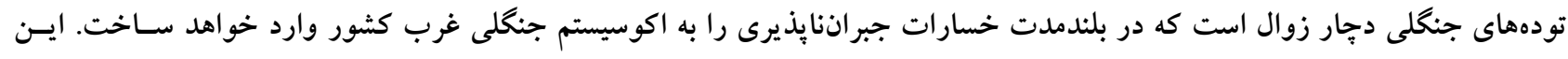

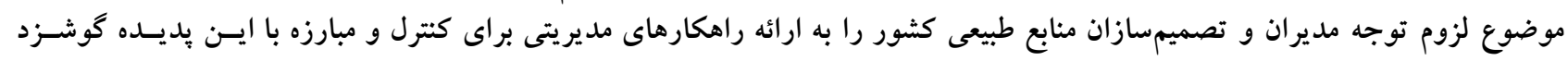

وازههاى كليدى: زى توده، كربن، خشكيدگى، جهارمحالوبختيارى

ا. استاديار يزوهش، بخش تحقيقات منابع طبيعى، مركز تحقيقات و آموزش كشاورزى و منابع طبيعى استان جهارمحالوبختيـارى، سـازمان تحقيقـات، آموزش و ترويج كشاورزى، شهركرد.

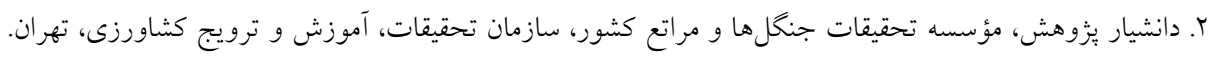

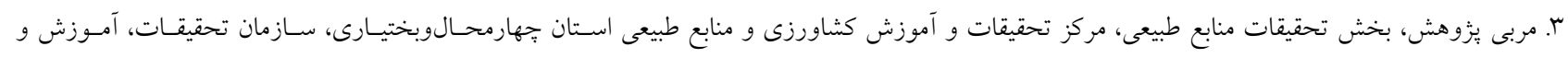
ترويج كشاورزى، شهركرد.

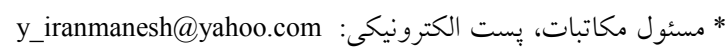


مىشود (Y). آكاهى از زى توده درختى بهمنظور ارزيسابى مقــدار

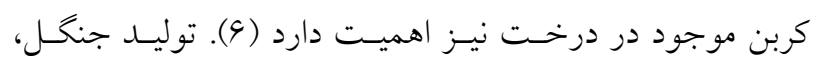

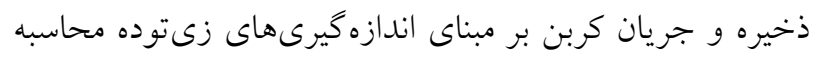

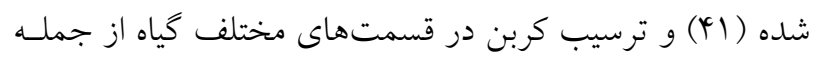

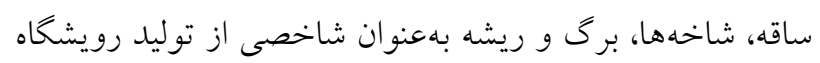

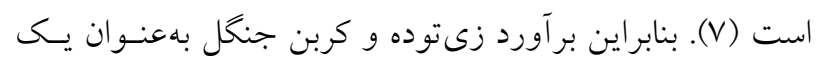

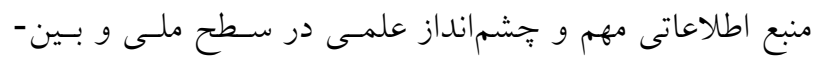

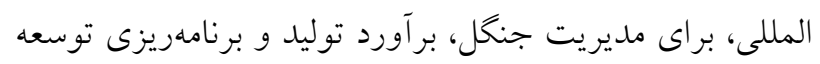
ملى ضرورى است (YV) (ب). ميزان فتوسنتز، مقدار كل كربن تثبيـتشـــه توسط بـرى را را مشخص مى كند، اخر جهه مقدار كربن تثبيتشده براى انتقـال، بـهـ عوامل ديخرى نيز وابسته است. تنظيم مقدار كربن تثبيتشده در مسيرهاى متابوليكى مختلف را بهاصطلاح "تقسيم" مسى كوينـد.

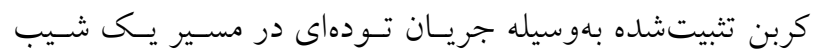

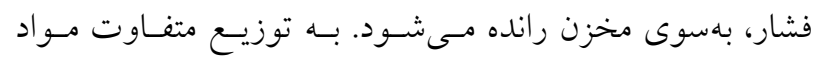

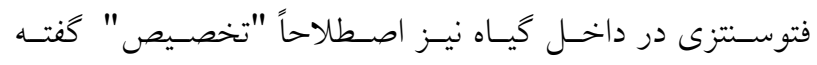

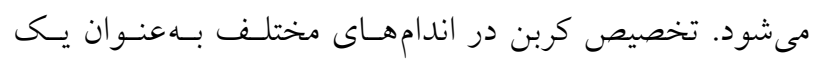

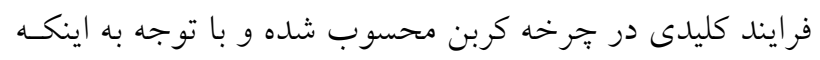

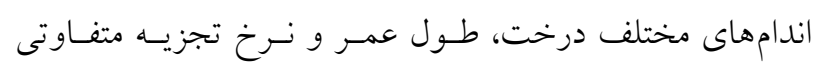

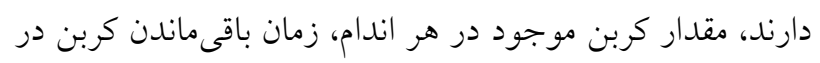
اكوسيستم و جرخه كربن آن را تعبين مى كند (rاس). Muukkonen

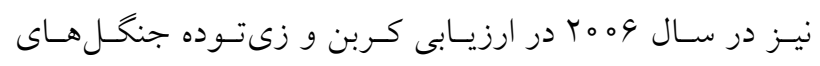

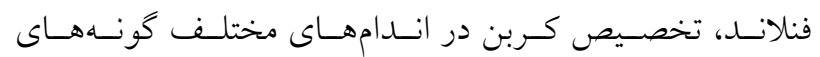

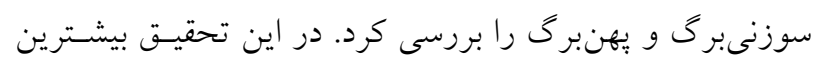

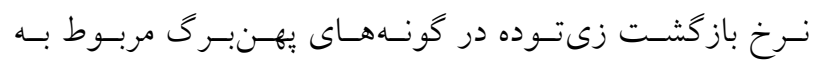

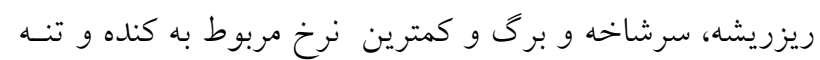

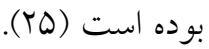
زوال بلوط فراينـدى يبحيجــه اسـت كـه در سطوح مختلـف درختى و توده جنگكلى عمل مى كند و مىتواند بر تركيب كونسهــا

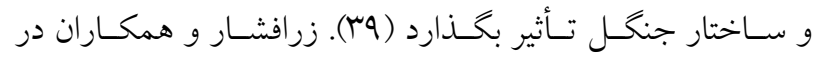
بررسى خشكيدكى تودهاى خالص بلوط ايرانسى در جنخـلهــاى

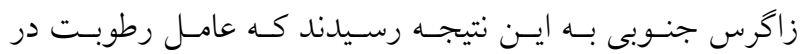

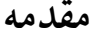

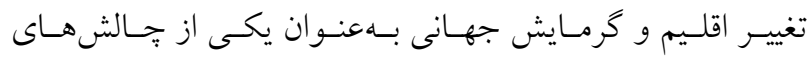

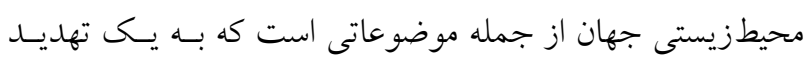

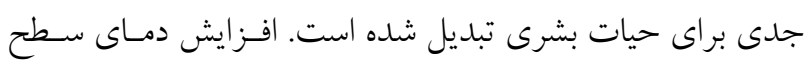

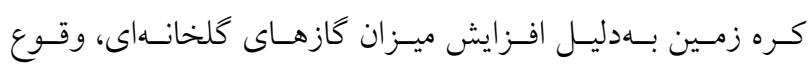

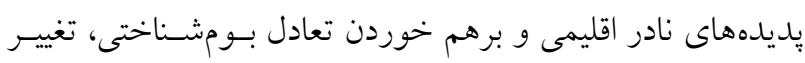

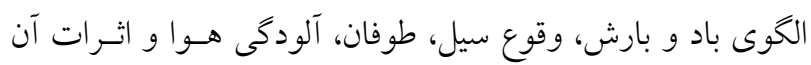

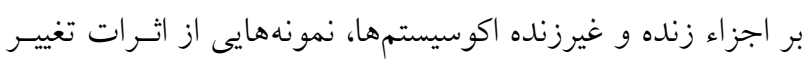

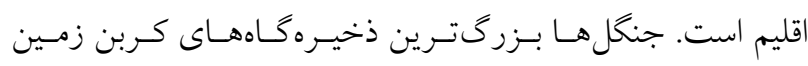

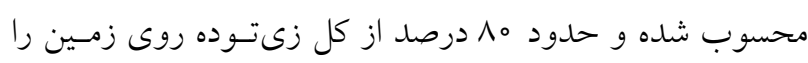

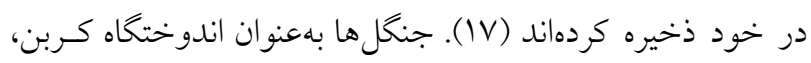

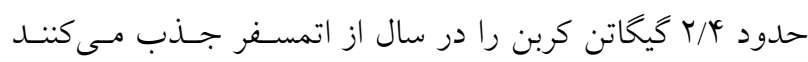

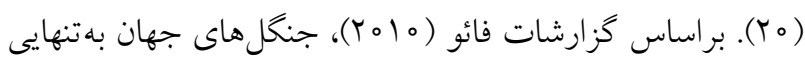

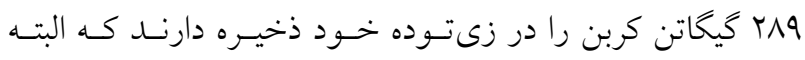
بهدليل تخريب و كاهش سطح جنغل هاى دنيا، اين ذخيره در بسين

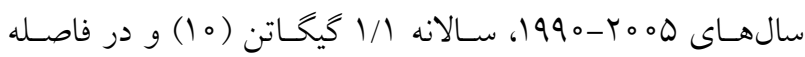

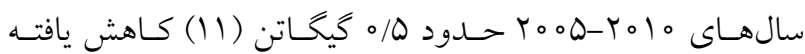
است. تخمين زده مىشود كـه فعاليـتهـاى جنخـل دارى، سـالانه

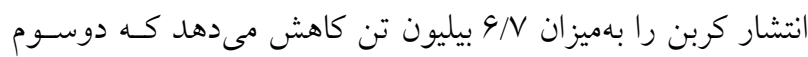

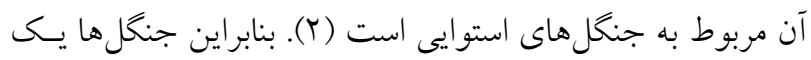

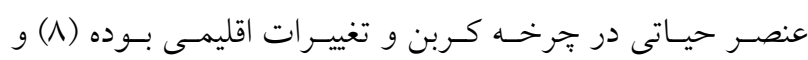

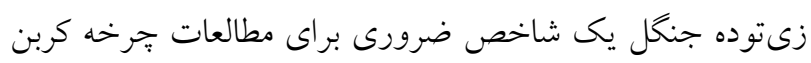

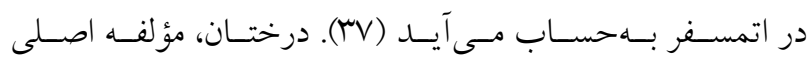

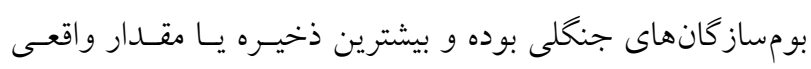

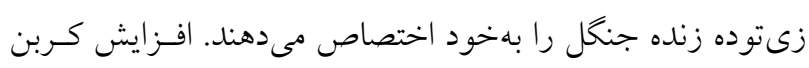

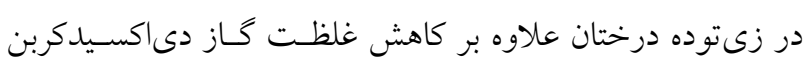

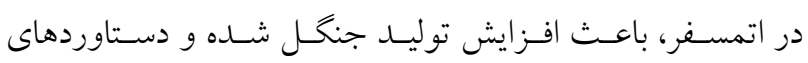
محيطزيستى مهمى را بههمراه خواهد داشت. برآورد زى توده درخت در ارزيابى ساختار و شرايط جنيخل

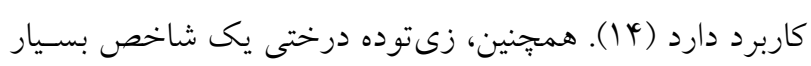

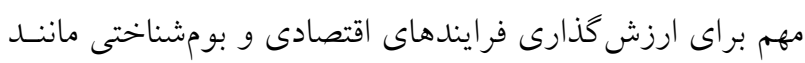

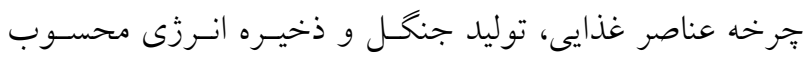


(روستاهاى قلعهسماع و جيخو) و شهرستان كيـار (روستاهاى

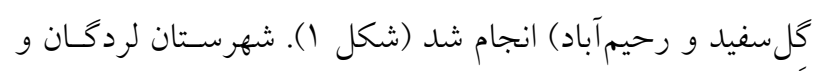

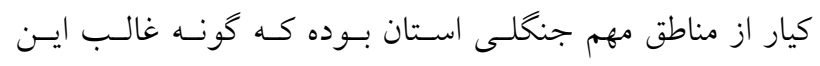
جنخل ها، بلوط ايرانى است.

\section{روش ئزوهش}

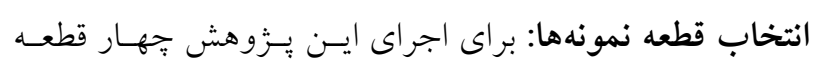

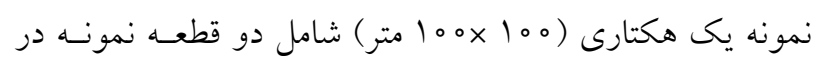

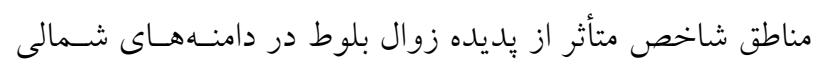

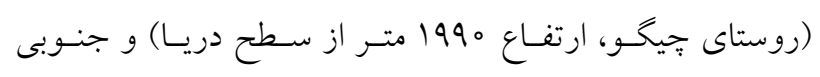

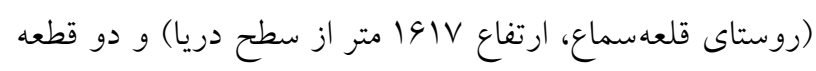

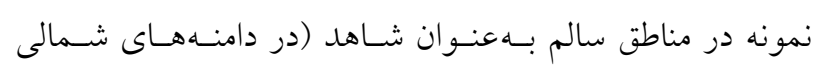

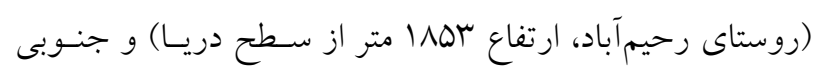

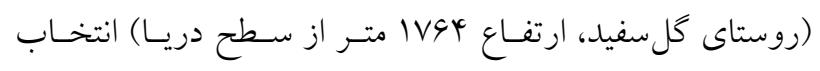

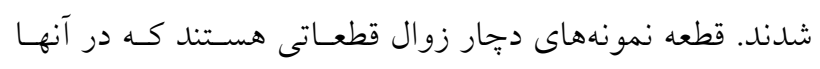

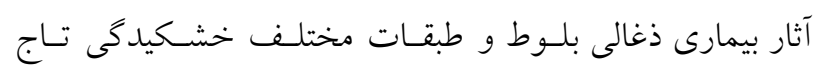

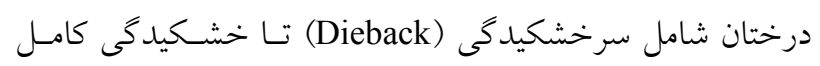
وجود دارد. در قطعه نمونههاى شـاهد، درختـان كـاملاً شـاداب

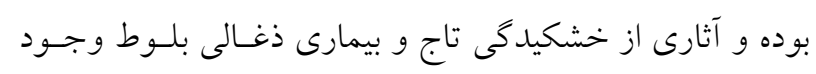

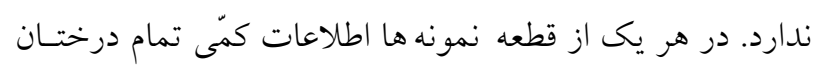

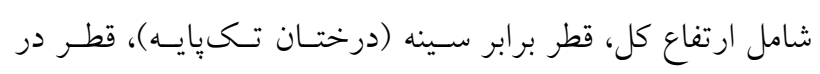

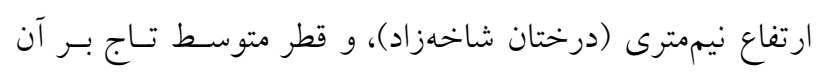

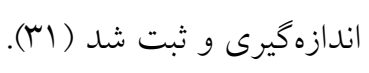

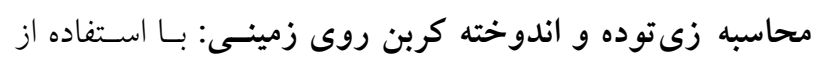

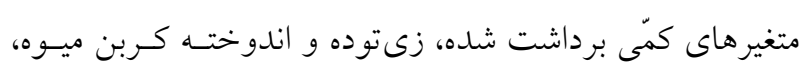

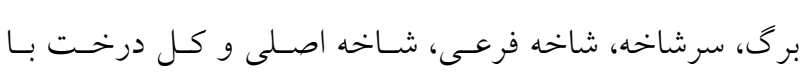

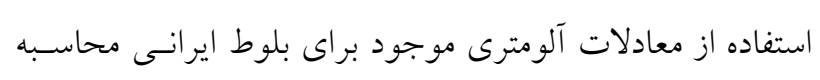

شد (1) ).

نمونه بردارى از لاش ريزه: نمونهبردارى از لاشريزه توسط يك هـ

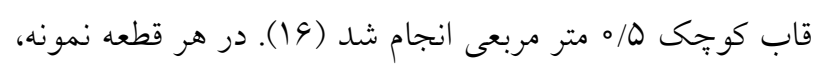

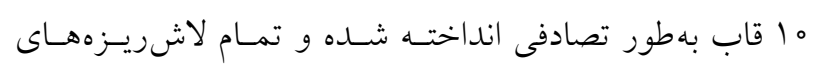

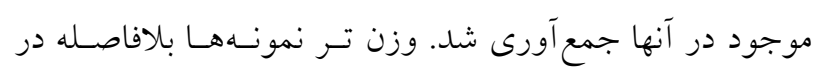

ريزوسفر ريشه نقش مهم و كليدى در شيوع خشكيدكى درختـان

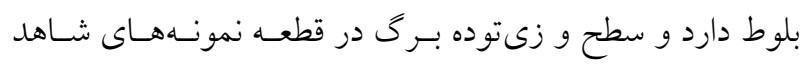

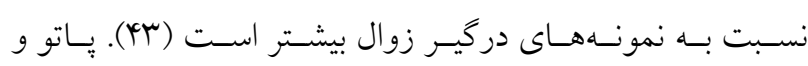

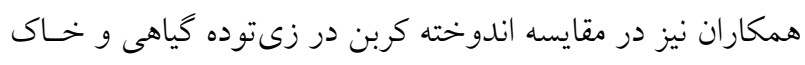

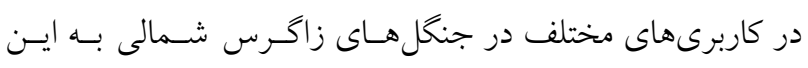

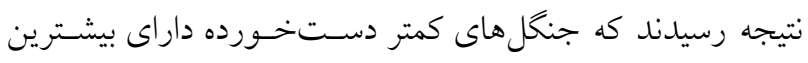

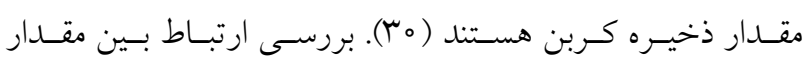

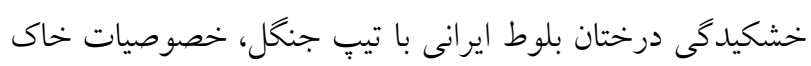

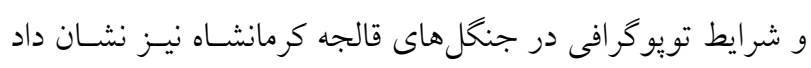

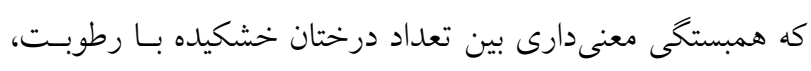
كربن، نيتروزن و بافت خاك وجود دارد (Yq).

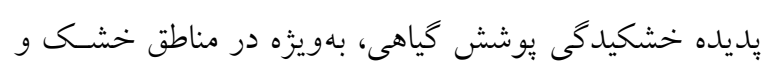

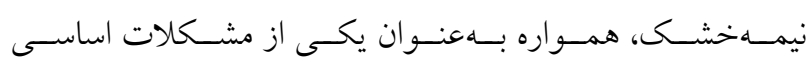

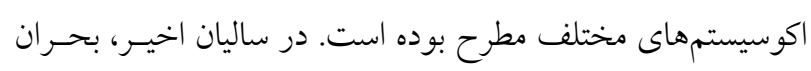

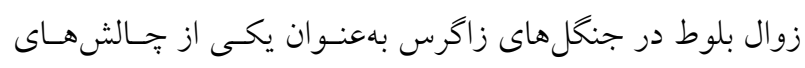

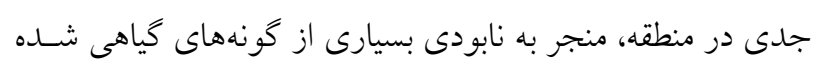

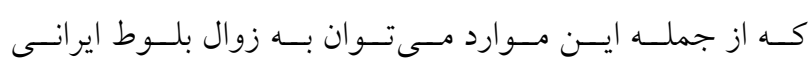

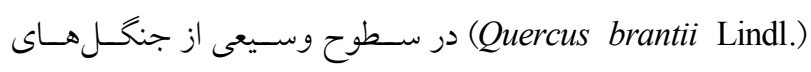

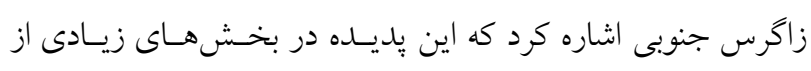

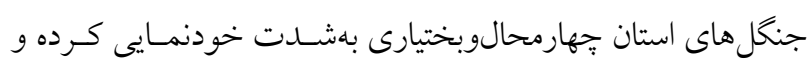
تغييرات محسوسى را در جهره ظاهرى اين جنكل ها بهوجـود آورده

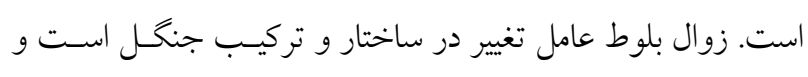

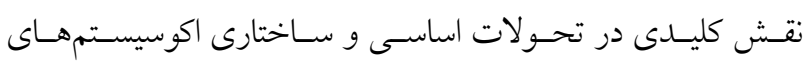

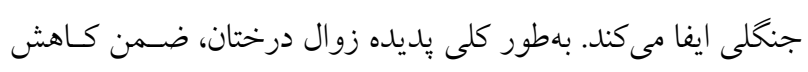

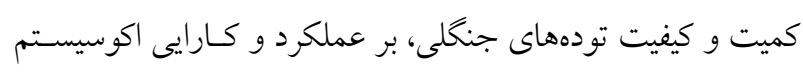

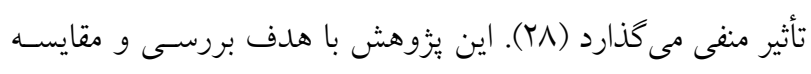

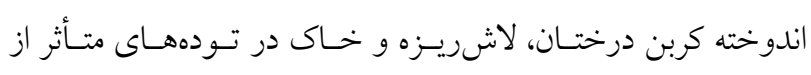
يديده زوال و تودههاى سالم انجام شد.

\section{مواد و روشها \\ منطقه مورد مطالعه}

اين بززوهش در استان جهارمحالوبختيـارى، شهرسـتان لردخـان 
بومشناسى كاربردى / سال دهم / شماره دوم / تابستان 1F。o
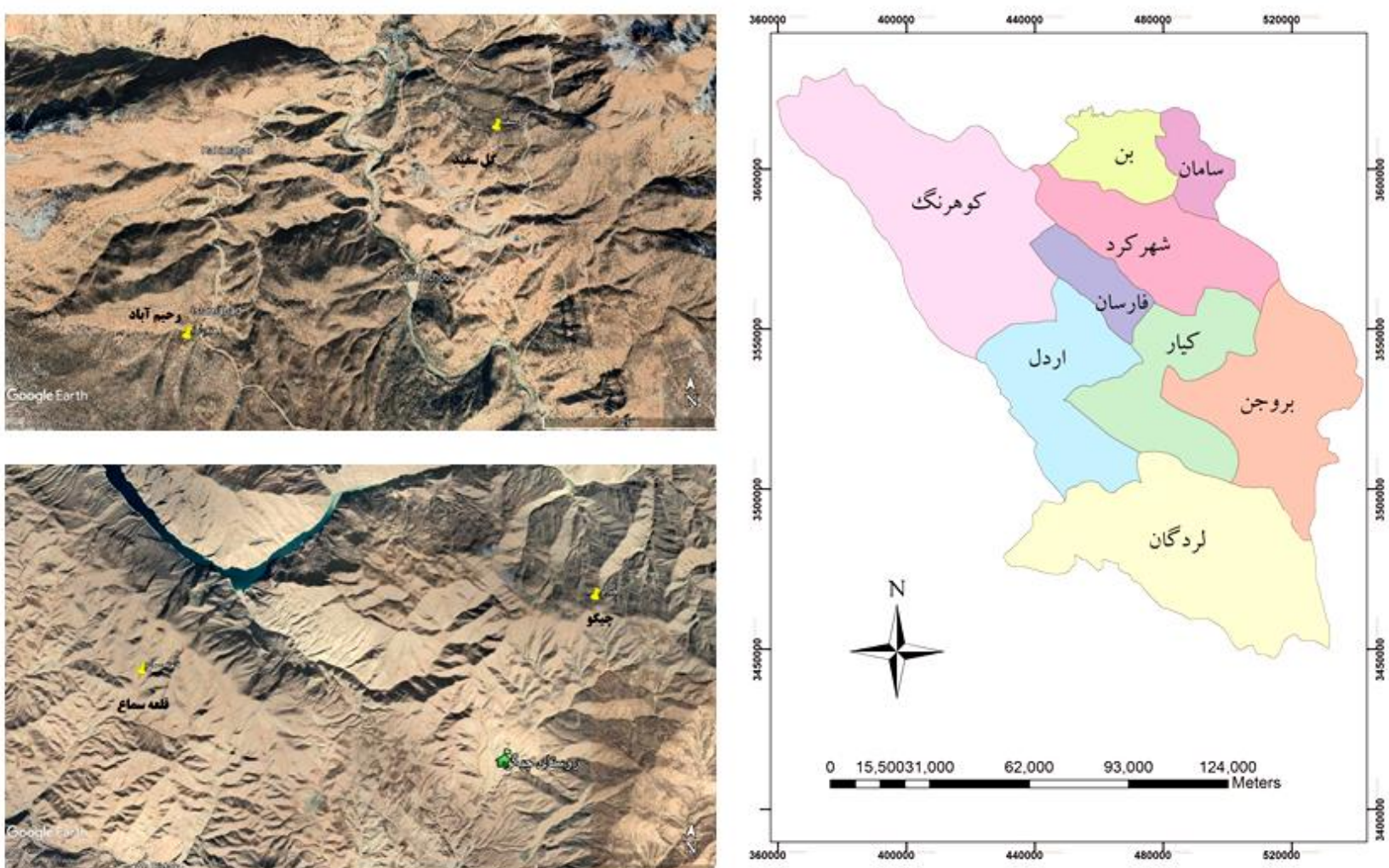

شكل 1. موقعيت قطعه نمونههاى مورد بررسى (رنكى در نسخه الكترونيكى)

اندازهيرى درصد كربن آلى نمونههاى گياهى، از روش احتراق

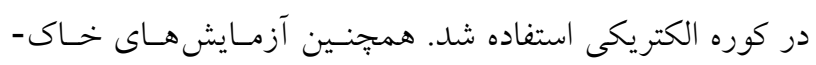

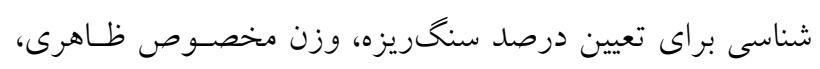

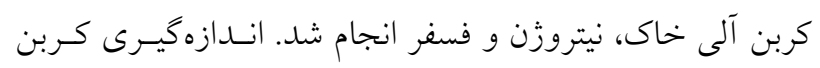

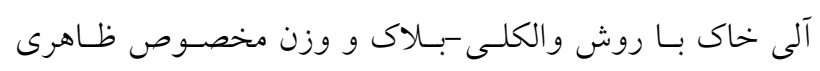
خاى با روش كلوخه تعيين شد (YY).

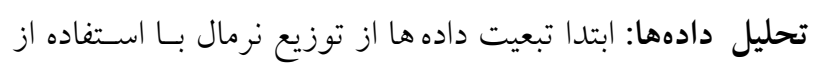
آزمون كولموكروف -اسميرونوف بررسى شد. به منظـور مقايسـهـ

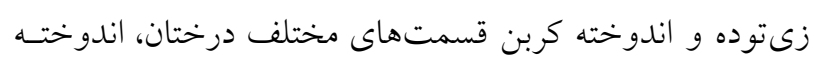

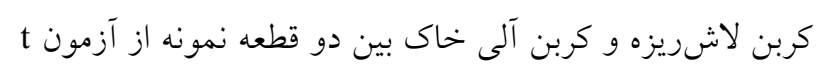
مستقل استفاده شد.

نتايج

ويزّكى هاى توصيفى درختان در قطعه نمونهها

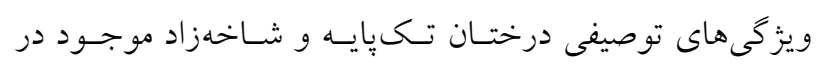

عرصه توزين شده و نمونهها در بستهبندىهاى جداكانه، بهمنظور

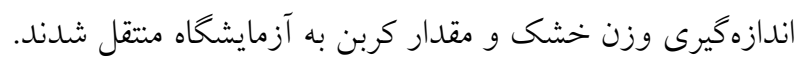

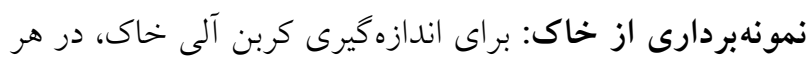

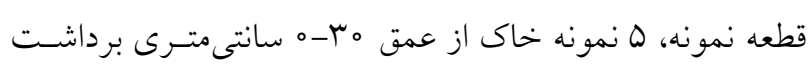

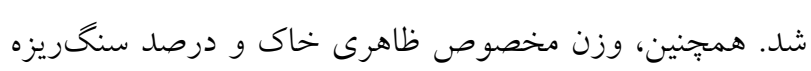

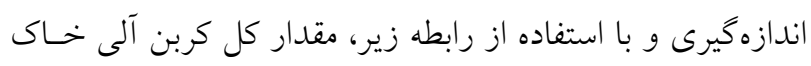
در هر هكتار از هر قطعه نمونه محاسبه شد (IV) SOC $=[\mathrm{SOC}] \times$ Bulk Density $\times$ Depth $\times$ Coarse Fragments $\times 10$

كه در آن: SOC غلظت كـربن آلى خـاك، Bulk Density وزن

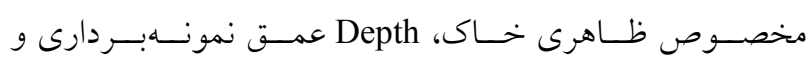
Coarse Fragments

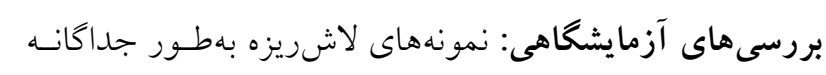

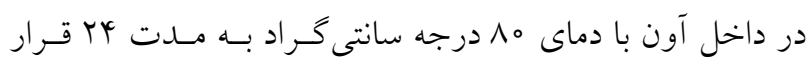

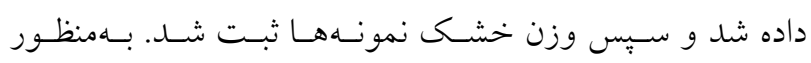


روى زمينى در هر بايه در قطعات شاهد به طـور متوسـط OV9

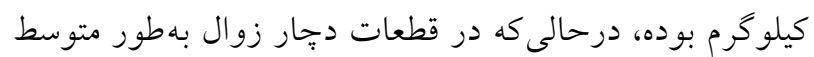
109/1 كيلو گرم است (جدول Y) و اين تفاوت از نظر آمـارى در سطح اطمينان 99 درصد معنى دار است. همجنين، در همـه قسمت هاى مختلـف درخـت تفـاوت معنسى دارى بـين قطعـه

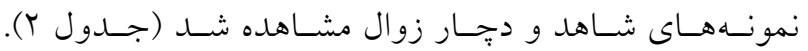
بيشترين زىتوده روى زمينسى در تنسه و كمتسرين آن در ميـوه وجود دارد. بخشش عمده زى توده درختان در قطعه نمونسههـاى مورد بررسسى در قسـمت تـاج (شـاخههـاى اصسلى و فرعسى، سرشاخه، برگ و ميوه) وجود دارد. نتـايج بـــرآورد اندوختـهـ كـربن روى زمينسى بــا اسـتفاده از

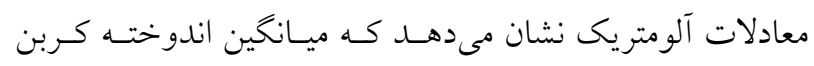
روى زمينى در قطعـات شـاهد / / ا و در قطعـات دجهـار زوال V/V

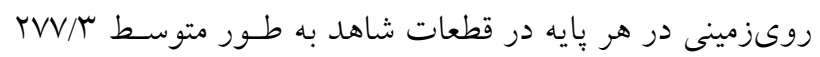

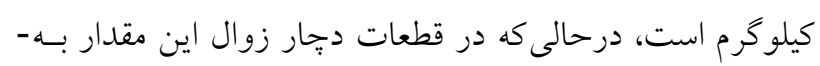
طور متوسط VA/A كيلو گرم است كه اين تفاوت از نظـر آمـارى در سطح اطمينـان 99 درصــ معنسى دار اسـت. در قسـمتهـاى مختلف درخت نيز تفاوت معنى دارى بين قطعه نمونهاى شاهد و دجّار زوال مشاهده شد (جدول ب). بيشترين اندوختـه كـربن

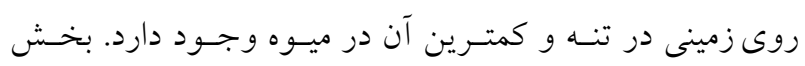
عمده كربن موجود در درختان مـورد بررسسى در قسـمت تـاج (شاخههاى اصلى و فرعى، سرشاخه، برى و ميوه) ذخيـره شـده

\section{اندوخته كربن لاشرريزه}

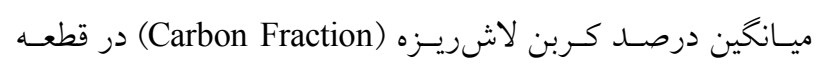

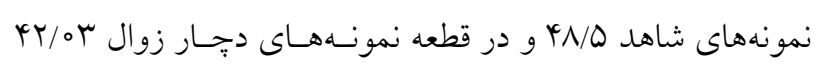
درصد بـهدست آمـد كـه ايسن اخـتلاف از نظـر آمـارى تفـاوت

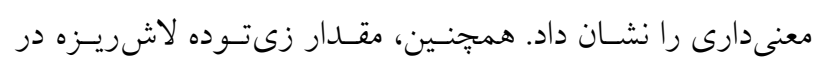

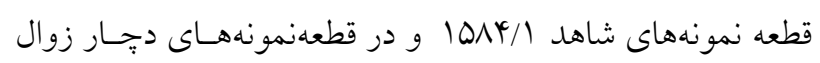

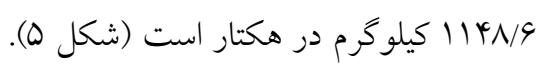

قطعه نمونهها در جدول ا ارائسه شـده اسـت. در قطعسه نمونـه

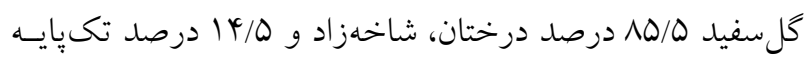
هستند. همجنين درختان شاخهزاد نسبت به درختـان تكىِايسه، قطر تاج و ارتفاع بيشترى دارند، اما درختـان تـكيايسه قطـورتر

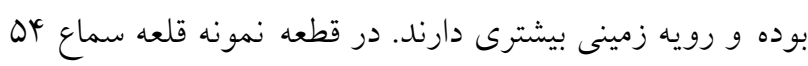
درصد درختان، شاخهزاد و و4 درصد تكى پايسه هسـتند. در ايسن قطعه نمونه نيز درختان شاخهزاد نسبت به درختان تكىبايه، قطر تاج و ارتفاع بيشترى دارند، اما درختان تكىيايه قطـورتر بـوده و

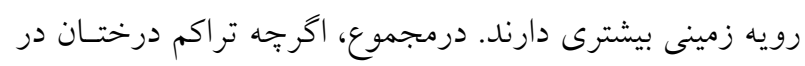
قطعه نمونه كل سفيد كمتر از قطعه نمونه قلعه سماع اسـت، امـا درختان قطعه نمونه كل سفيد نسبت به قطعه نمونه قلعـه سـماع، قطر، ارتفاع و قطر متوسط تاج بيشترى دارند.

\section{تخصيص زى توده روىزمينى}

در قطعه نمونسههــاى شـمالى و جنـوبى متـأثر از زوال، بـهـــور متوسط VD/I و 9V/I درصد از كل زى توده به تنه و شاخههـاى اصلى درختان اختصاص يافته است. در قطعه نمونههاى شـمالى لى لئ و جنوبى شاهد نيز بهطور متوسـط وV/I و VD/V درصــ از كـل

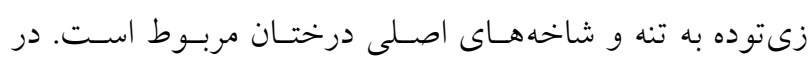
مجموع در قطعه نمونههاى شاهد ميزان تخصسيص زىتـوده بـهـ قسمت هاى جوبى درخت (تنه و شـاخههـاى اصسلى و فرعى)

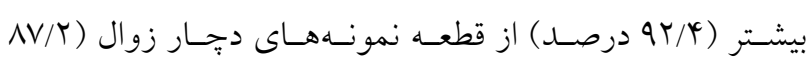
درصد) است. بـهـ عبـارت ديخـر، در قطعـه نمونـههــاى شـاهد، تخصيص زىتـوده بـه قسـمتهــاى غيرجــوبى (ميـوه، بـرى و سرشاخه) V/9 درصد و در قطعه نمونههـاى متــأثر از زوال ايسن

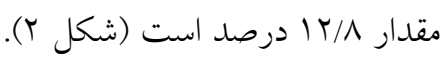

\section{زى توده و اندوخته كربن روى زمينى}

نتـايج بــر آورد زى تـوده روى زمينسى بـا اسـتفاده از معـادلات

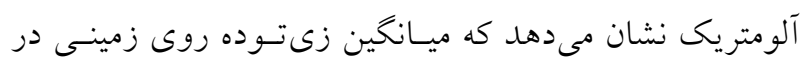

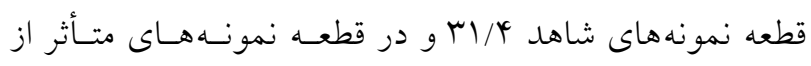

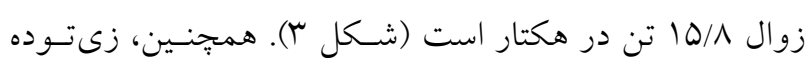




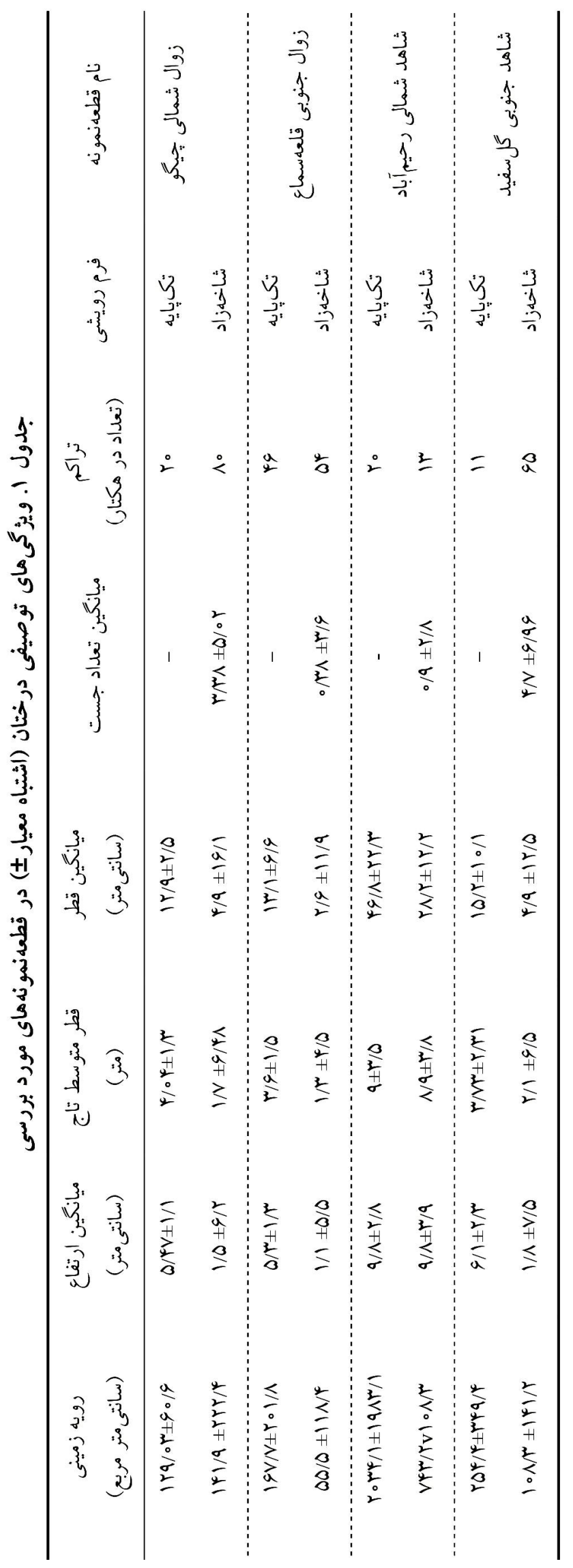



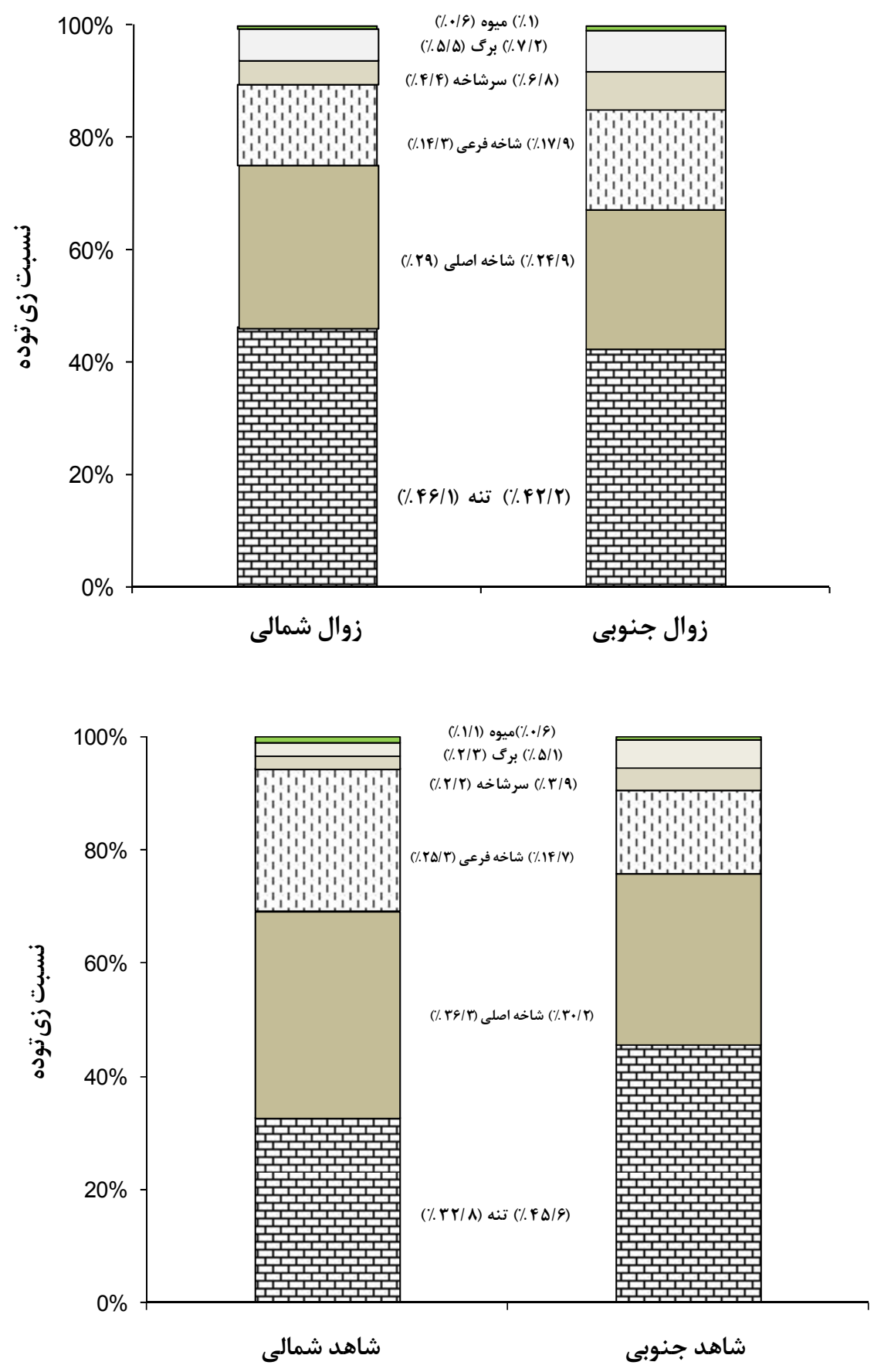

شكل Y. مقدار تخصيص زىتوده در قسمتهاى مختلف درختان در قطعه نمونههاى مورد بررسى (رنكى در نسخه الكترونيكى)

نمونههاى شـاهد V0/T و در قطعسه نمونسهــاى دجـار زوال

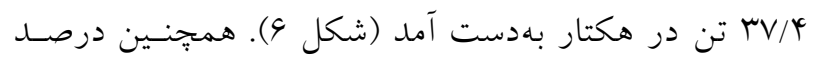

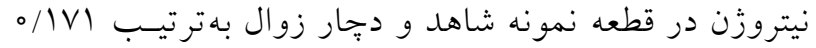

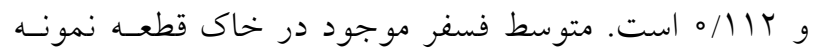

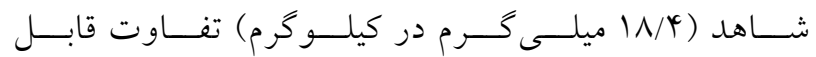

اندوخته كربن، نيتروزن، فسفر و رطوبت خاك

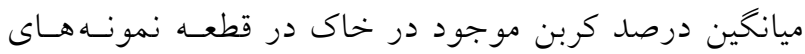
شاهد /T/ و در قطعه نمونه دجار زوال // درصد است. بـا توجه به مقدار سنگريزه و وزن مخصوص ظاهرى خاى در قطعات مورد بررسى، ميانحين اندوخته كربن موجود در قطعه 


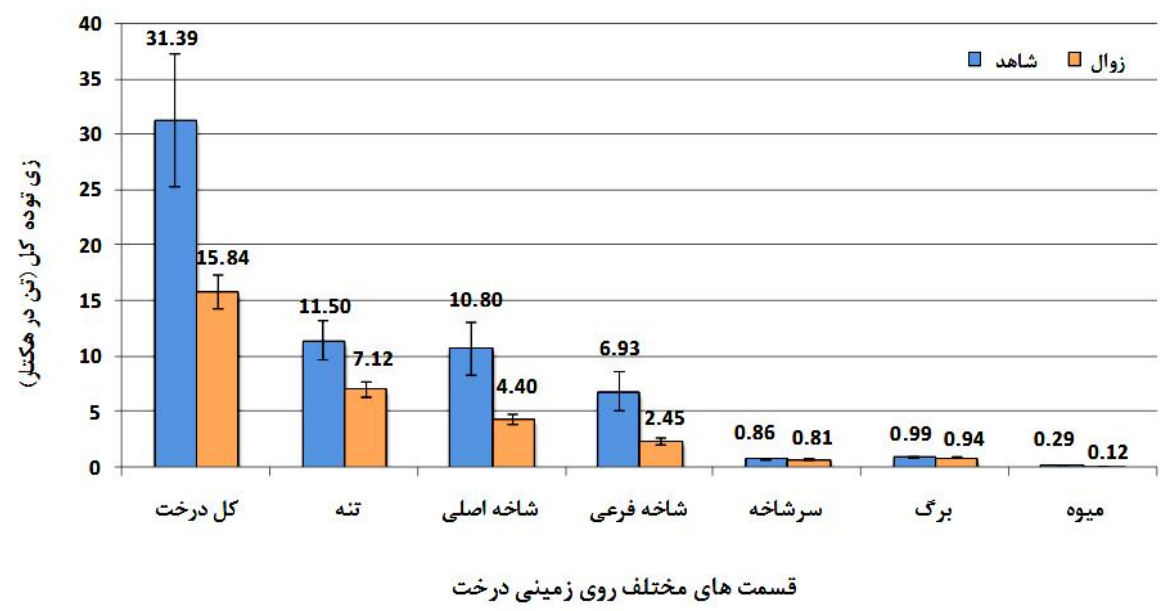

شكل r. مقايسه زى توده روى زمينى قسمتهاى مختلف درختان موجود در قطعه نمونهاى مورد مطالعه (رنكى در نسخه الكترونيكى)

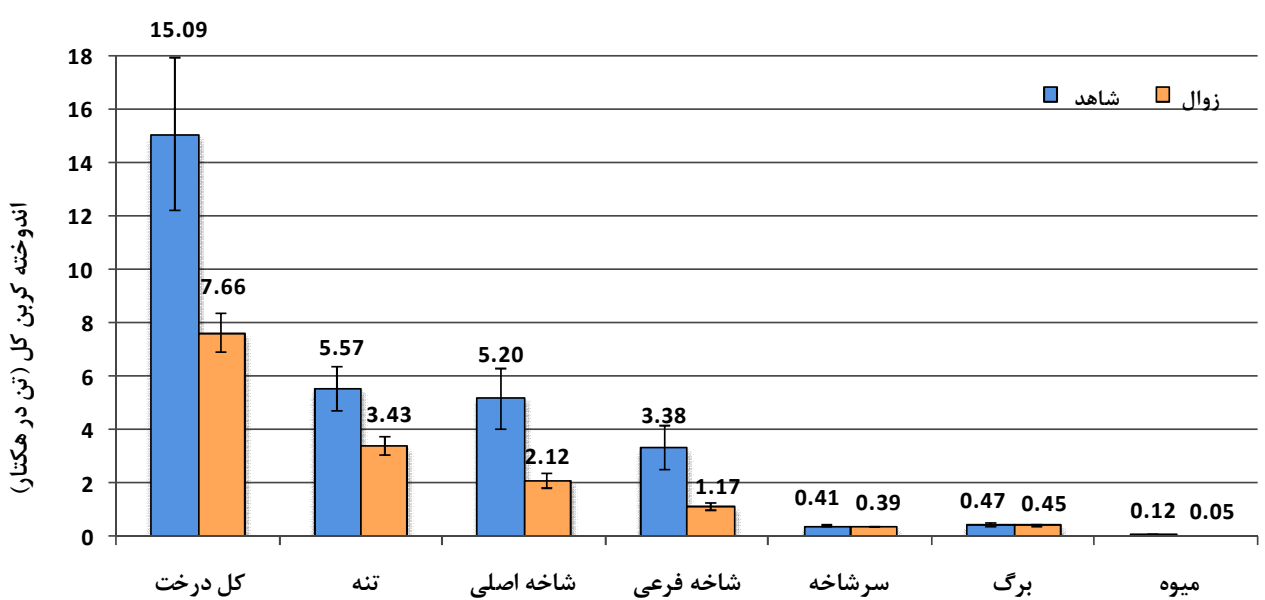

قسمت هاى مختلف روى زمينى درخت

شكل أ. مقايسه اندوخته كربن روىزمينى قسمتهاى مختلف درختان موجود در قطعه نمونه ماى مورد مطالعه (رنكى در نسخه الكترونيكى)

جدول Y. نتايج آزمون t مستقل مقايسه ميانخين زى توده قسمتهاى مختلف درختان در هر يايه بين قطعه نمونههاى مورد بررسى

\begin{tabular}{|c|c|c|c|c|c|c|c|}
\hline كل & تنه & شاخه اصلى & شاخه فرعى & سرشاخه & برى & ميوه & \\
\hline OVG & $r \| / r$ & $191 / 4$ & $I T V / T$ & $10 / V$ & $1 N / T$ & $\Delta / \Gamma$ & شاهد \\
\hline $109 / 1$ & $V 1 / d$ & $k+/ 1$ & $T Y / D$ & $N / T$ & $9 / 9$ & $1 / r$ & زوال \\
\hline ** & ** & ** & ** & ** & ** & ** & sig \\
\hline
\end{tabular}

جدول س. نتايج آزمون t مستقل مقايسه ميانكين اندوخته كربن قسمتهاى مختلف درختان در هر يايه بين قطعه نمونهاى مورد بررسى

\begin{tabular}{|c|c|c|c|c|c|c|c|}
\hline كل & تنه & شاخه اصلي & شاخه فرعي & سرشاخه & برى & ميوه & \\
\hline$r V V / r$ & $1 \circ Y / 1$ & $90 / r$ & $91 / V$ & $V / 0$ & $1 / 9$ & $r / l$ & شاهد \\
\hline$V \varepsilon / \Lambda$ & $M Y / V$ & $r / / \mu$ & $11 / 9$ & $r / q$ & $\varphi / 0$ & $\circ / \Delta \mu$ & زوال \\
\hline$* *$ & $* *$ & ** & ** & $* *$ & ** & ** & sig \\
\hline
\end{tabular}



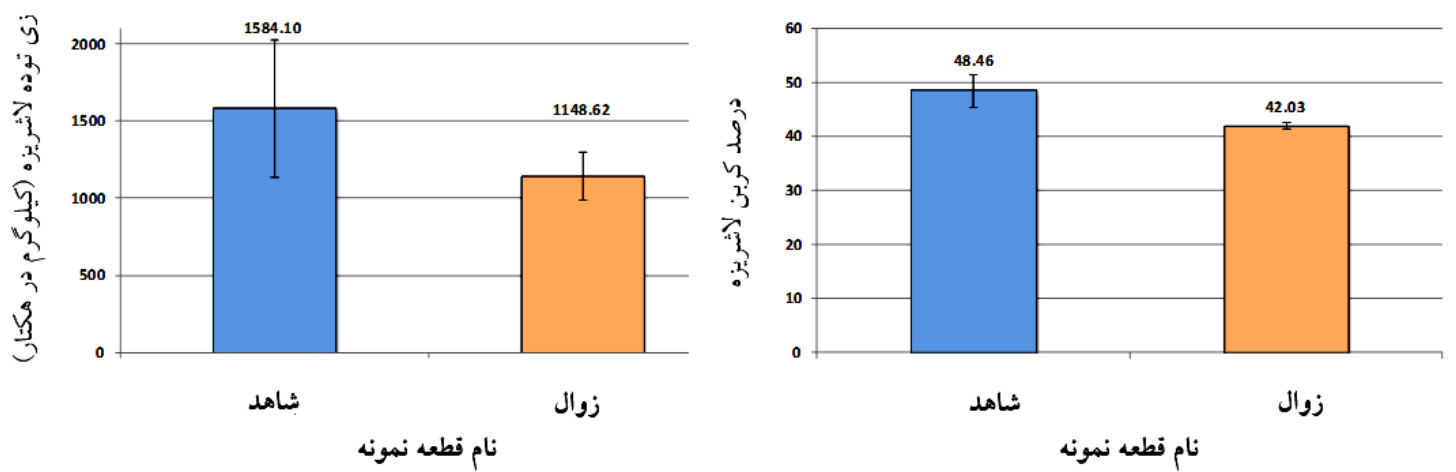

شكل ه. مقايسه درصد كربن (راست) و زى توده لاشريزه (جֶ)) در قطعه نمونههاى مورد مطالعه (رنكى در نسخه الكترونيكى) جدول أ. نتايج آزمون t مستقل مقايسه ميانگين زىتوده و درصد كربن لاشريزه در قطعه نمونهاى مورد بررسى

\begin{tabular}{|c|c|c|}
\hline زىتوده (كيلو گرم در هكتار) & درصد كربن & \\
\hline $10 \wedge 4 / 1$ & $\uparrow \wedge / 4 \varphi$ & شاهد \\
\hline $11 Y N / 9 T$ & $Y Y / O r$ & زو ال \\
\hline$* *$ & $* *$ & معنى دارى \\
\hline
\end{tabular}

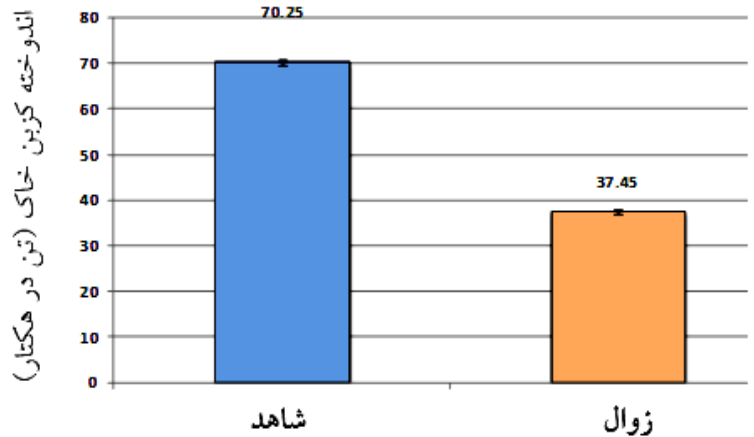

ثام ثطعه ثموثه

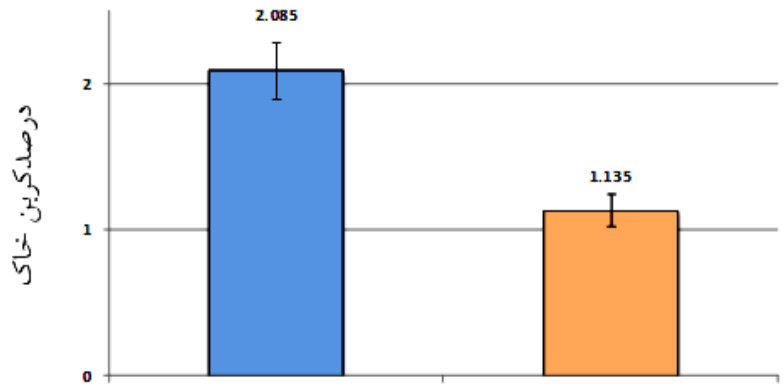

شاهد
زوال

نام تطعه نموثه

شكل 9. مقايسه درصد كربن (راست) و اندوخته كربن خاك (جֶ) در قطعه نمونهاى مورد مطالعه (رنكى در نسخه الكترونيكى)

نيازهــاى اساسـى در برنامــهريـزىهــاى مــديريتى جنخخـل و بررسىهاى جريان انرزى در اكوسيستم بهحساب مى آيد كه ايسن موضوع طى ساليان اخير مـورد توجسه بسـيارى از بزوهشــران

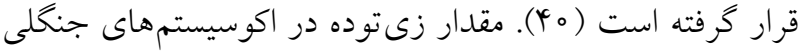
علاوهبر اينكه بيانكر توان توليد در واحد سطح يا زمـان (مقـدار

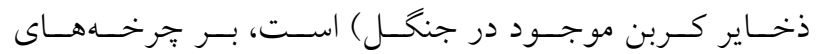

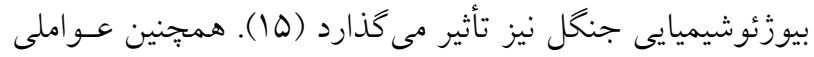

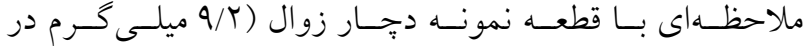
كيلوگرم) نشان داد. ميانخين رطوبت خاك نيـز در قطعسه نمونسه شاهد 9/9 و در قطعه نمونه دجار زوال V/T درصد بهدست آمد

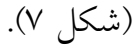

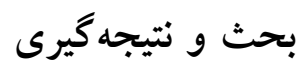

اندازه كيرى و برآورد زىتوده گياهان و بهويزه درختان، يكى از 


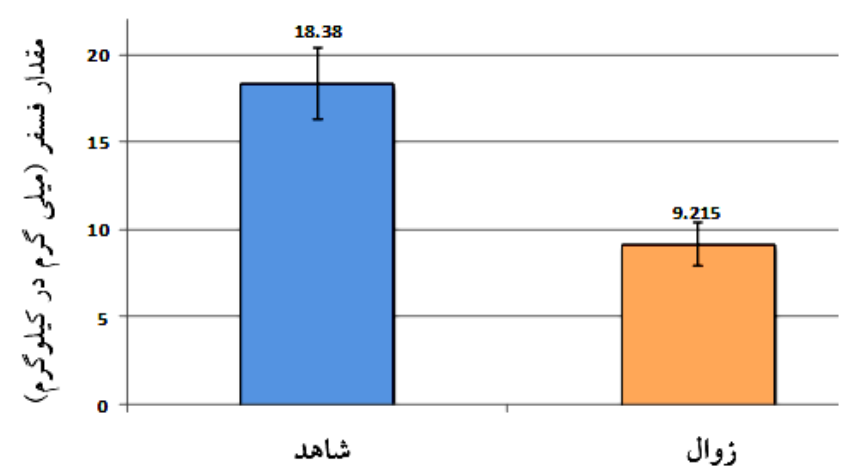

نام ثطعه ثموثه

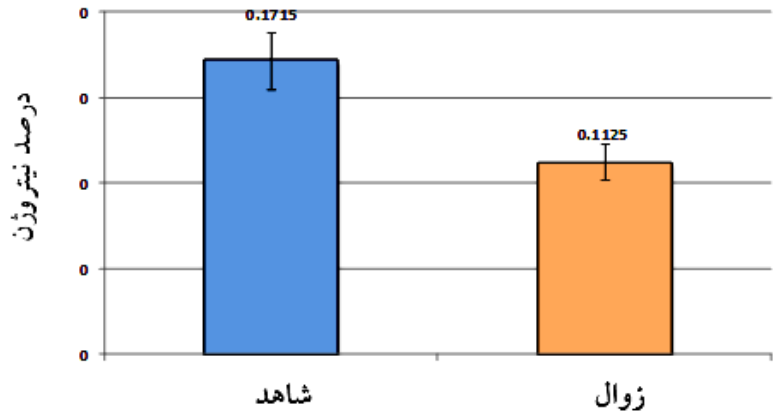

ثام قطعه ثمونه

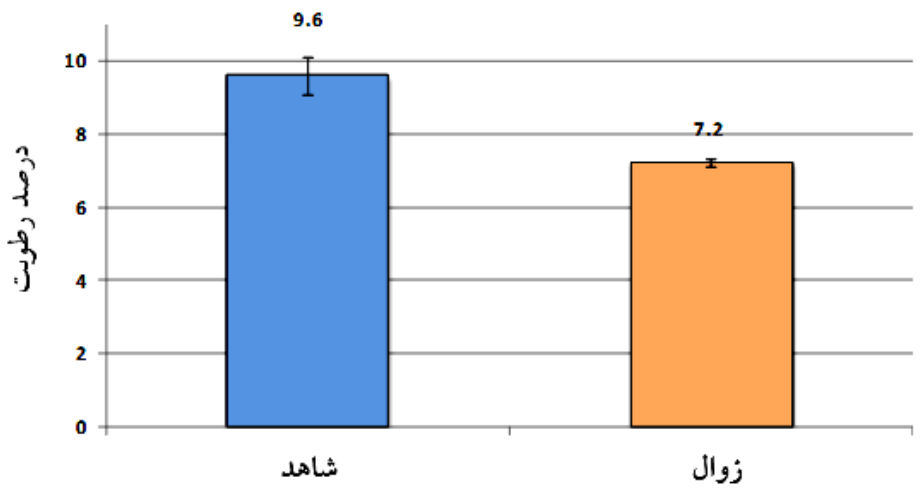

ثام ثطعه نموثه

شكل v. مقايسه مقدار نيتروزن (راست)، فسفر (جֶٍ) و رطوبت خاكى (پايين) در قطعه نمونههاى مورد مطالعه (رنكى در نسخه الكترونيكى)

معنى دارى بر اندوخته كربن اكوسيستم دارد. همجنين در شرايط

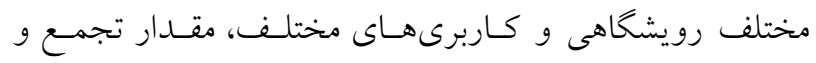

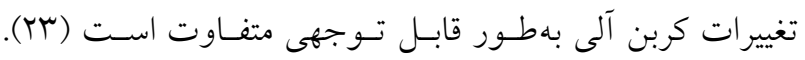

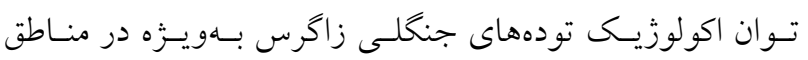

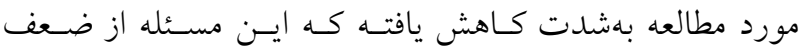

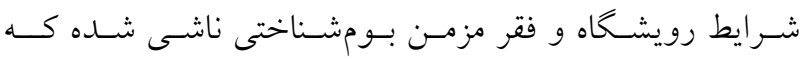

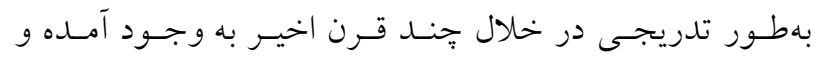

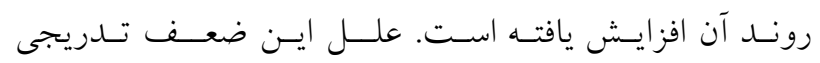

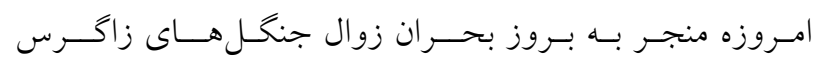

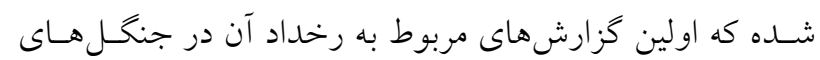

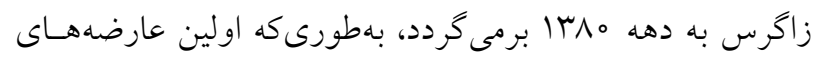

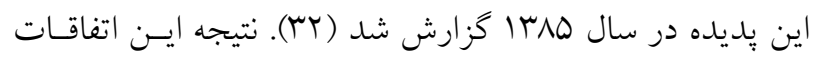

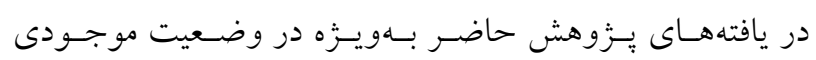

مانند بحران كرمايش جهانى و تعيين مقدار كربن ذخيرهشـده در

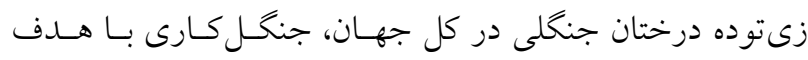

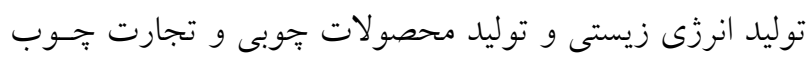

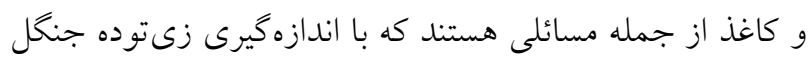

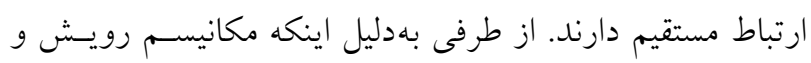

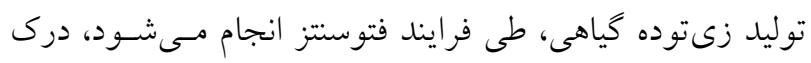

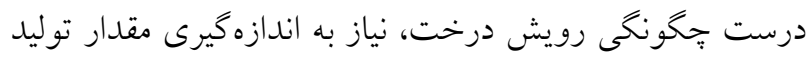

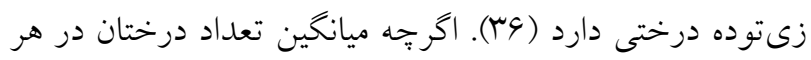

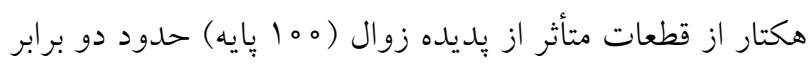

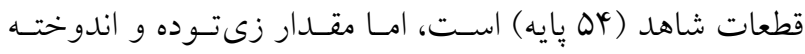
كربن در قطعه نمونهاى شاهد (†/آ تن در هكتار) بيش از دو برابر قطعه نمونههاى دجار زوال (10/1 تسن در هكتـار) اسـت.

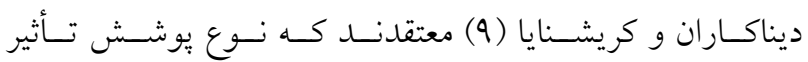


اين نتيجه رسيدند كه در هر دو فرم رويشى تكيايه و شاخهزاد،

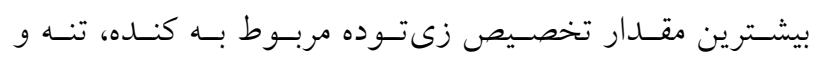
شاخههاى اصلى است كه با مطالعه حاضر مطابقت دارد (19).

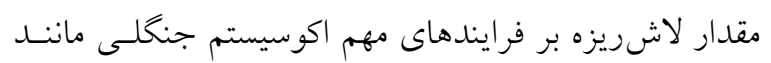

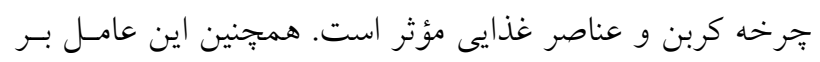

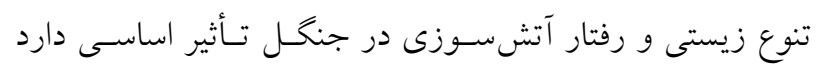

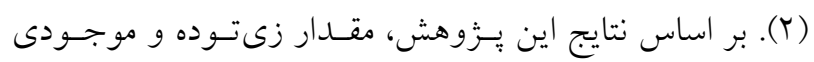

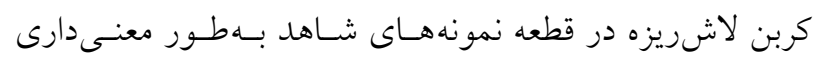

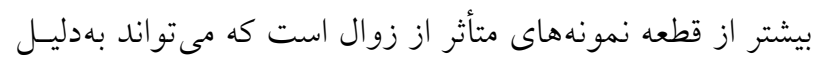

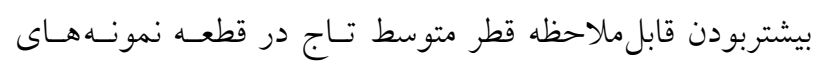

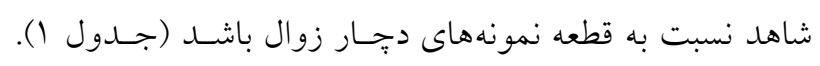

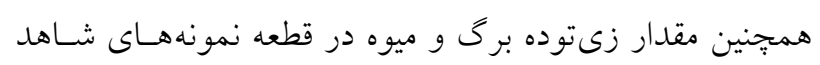

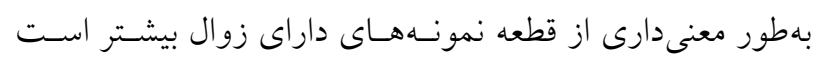

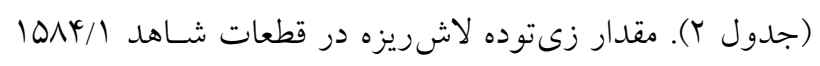

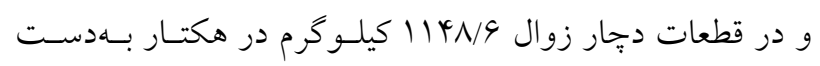

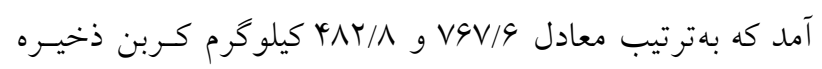
شــه در لاشريـزه در هـر هكتـار اسـت. خــادمى و همكـاران

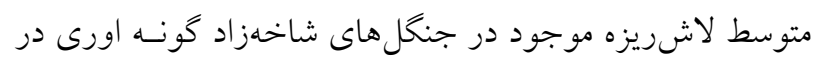

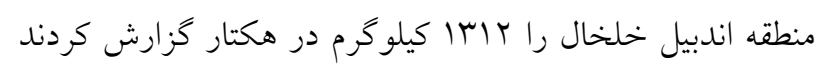

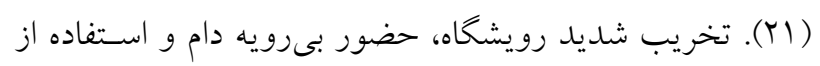

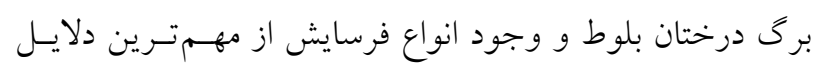

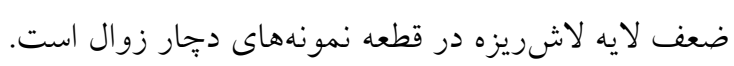

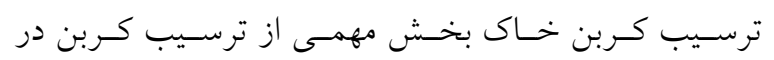

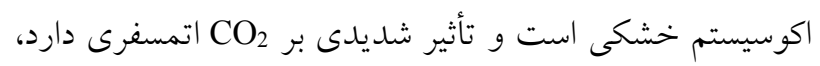

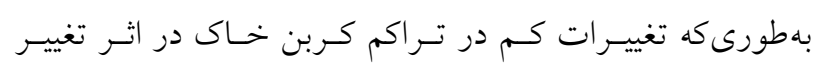
كاربرى اراضى ممكن است تغييرات زيادى در تراكم دى لـسكسيد

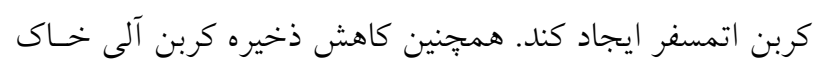

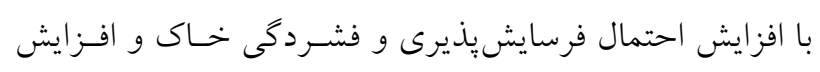

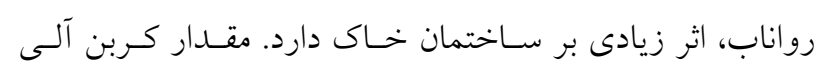

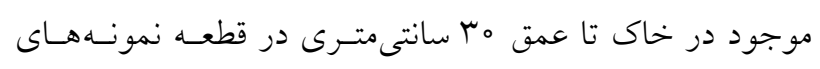

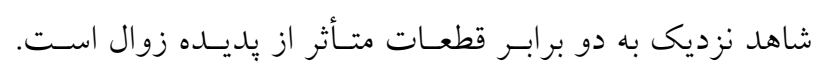

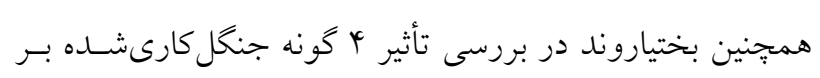

زى تــوده و اندوختـهـ كـربن رويشـعاه كـاملاً قابـل مشــاهده و

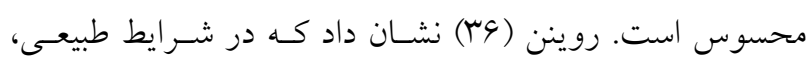

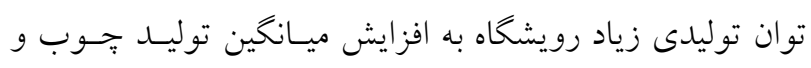

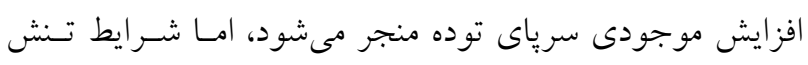

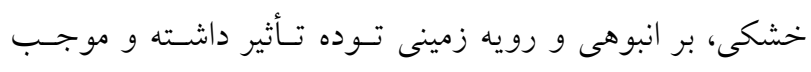
تشديد رقابت بيندرختى و افزايش مرگ و مير درختى مى شيود.

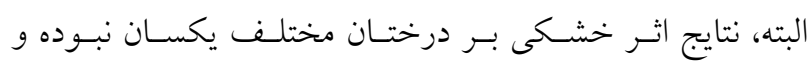

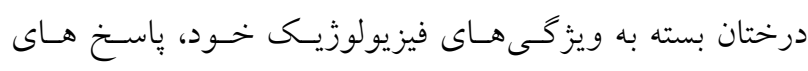

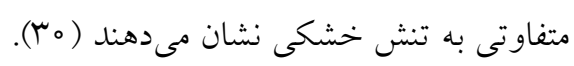

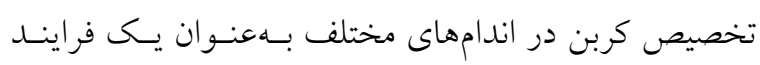

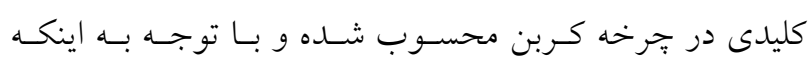

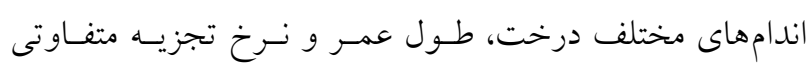

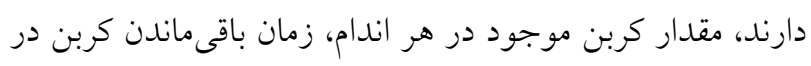

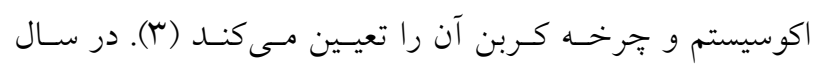

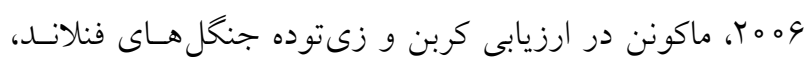

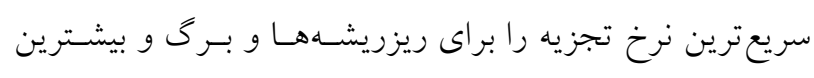

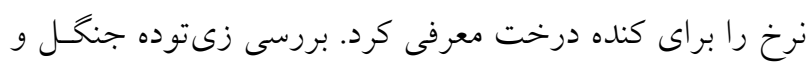

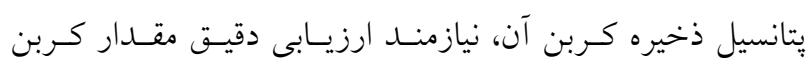

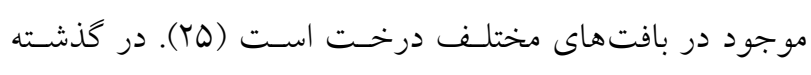

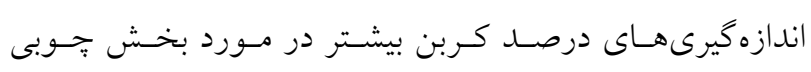

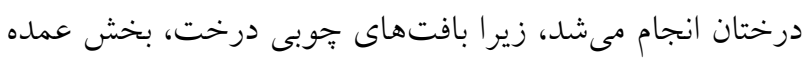

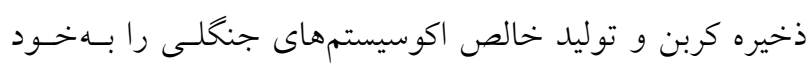

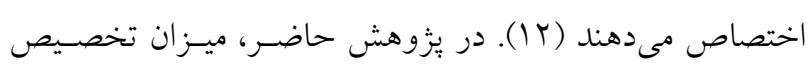

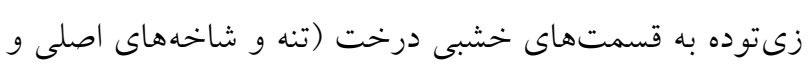
فرعى) در قطعه نمونه هاى شاهد بيشتر از قطعه نمونههاى ديخهار

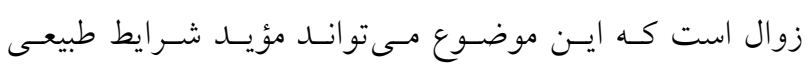

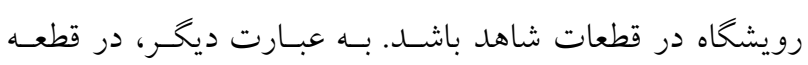

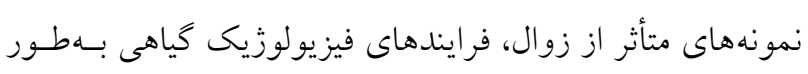

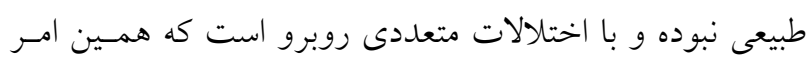

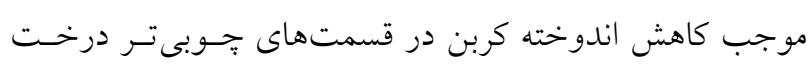

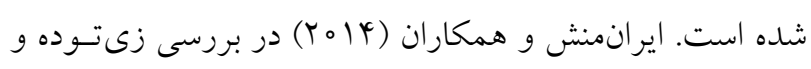

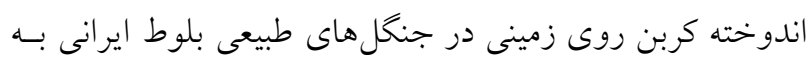


جدول ه. نتايج آزمون t مستقل مقايسه ميانخين اندوخته كربن، درصد كربن، نيتروزن، فسفر و رطوبت خاى بين قطعه نمونهاى مورد بررسى

\begin{tabular}{|c|c|c|c|c|c|}
\hline رطوبت & فسفر & 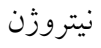 & اندوخته كربن (تن در هكتار) & درصد كربن & \\
\hline $9 / 9$ & $\mid \Lambda / \Upsilon \wedge$ & $\circ / \mid \mathrm{VI}$ & $V \circ / T \Delta$ & $r / \circ \Lambda$ & شاهد \\
\hline$V / T$ & $9 / Y_{1}$ & $0 / 11 Y$ & $M V / Y Q D$ & $1 / 1 \mu$ & ز ت موال \\
\hline$* *$ & $* *$ & $* *$ & $* *$ & ns & ت منى دارى \\
\hline
\end{tabular}

(** معنى دار در سطح اطمينان 99 درصد؛ ns غيرمعنى دار

نيتروزن خاك بيـانغر افـزايش ورود كـربن اسـت. بــا ايسن وجــود، شرايط بومشـناختى و رويشـحاهى مختلـف، يتانسـيل متفـاوتى در افزايش كربن آلى خاك دارند (צ؟). مطالعات نشـان داده اسـت كـه

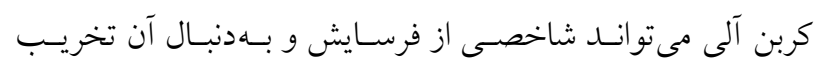

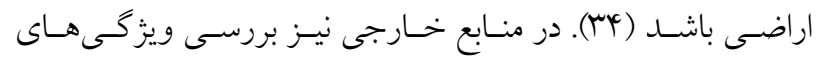
شيميايى خاك و زوال درختـان بلـوط (Q. robur) در جنخـل هــاى مرطوب منطقه آتلانتيك نشان داد كه با دسترسى به وضـعيت مـواد غذايى بهخوبى مىتوان زمان مرگ درختان بلوط را بيشبينى كرد.

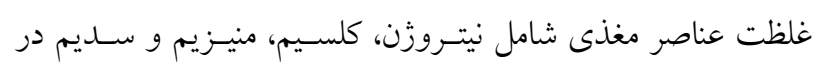

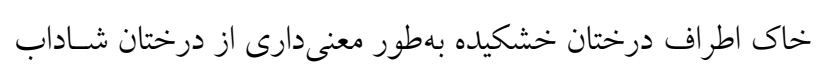
و زنده كمتر بود (هاr). (ه)

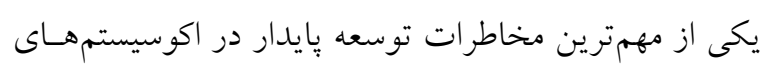
اقليمى شكننده، كرمايش جهانى و تغيير اقلسم ناشسى از انتشـار تصاعدى گازهاى كلخانهاى است كه معلول نابودى جنگلهــا و تخريب منابع اراضى و خاك است. در جنين وضـعيتى شـناخت

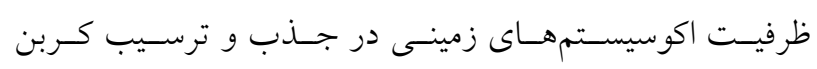

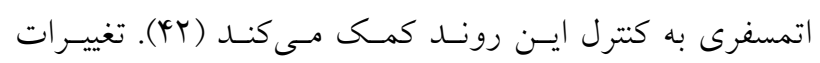

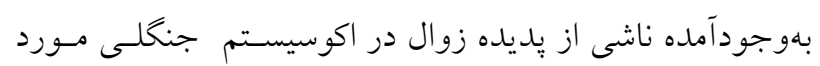

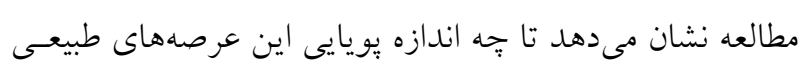
تغيير يافته و ظرفيت ذخيره كربن در زىتوده گياهى، لاشريـزه و خاى كاهش يافته است. تغييراتى كه جبران آن بهسختى قابـل انجام بوده و مستلزم صرف زمان و يرداخت هزينـههـاى بسـيار

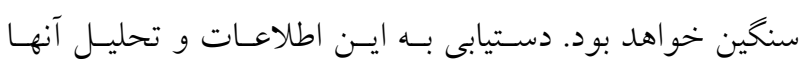

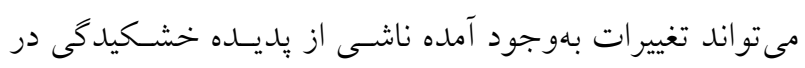
اكوسيستم جنخلى غرب كشور را بهخوبى نمايان ساخته و توجه

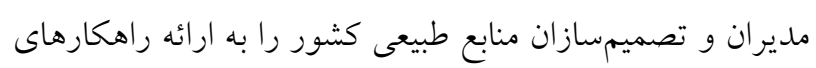

كربن خاك در منطقه فولاد مباركه اصفهان به اين نتيجـه رسـيد كـه نوع يوشش گياهى و گونه (يهنبرگ و سوزنىبرگ) بر روى مقـدار

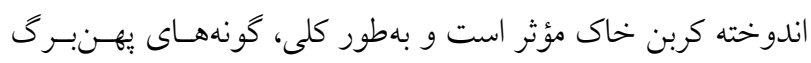
كربن بيشترى را نسبت به گونهاى سوزنىبرى در خـاك ترسيب

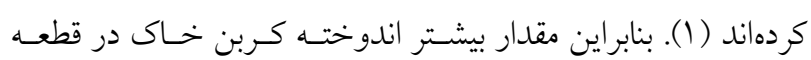
نمونههاى سالم را مىتوان ناشى از يويايى، كيفيـت و شـادابى تـوده در اين مناطق دانست. علاوه بر نقش كربن آلى خـاك در موضسوع كرمايش زمين و تغيير اقليم، كـربن آلى، ذخيـره رطـوبتى خـاك را

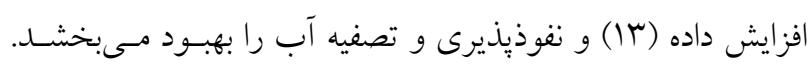
همجنين، تراكم و فشـردخى خـاك را كـاهش داده و از ايـن طريـق

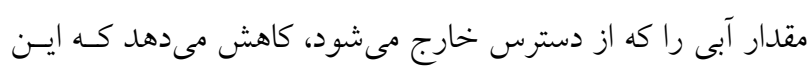
خود به معنى كاهش رواناب و سيلاب است ( (Y). مواد آلى همانند

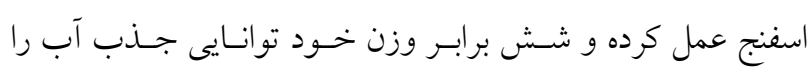
دارند (TV). بيشتربودن رطوبت خهاك در قطعـه نمونـهـــاى شـاهد (9/9 درصد) نسبت به قطعه نمونه هاى دجار زوال (V/T درصد) نيز تأييدكنتده اين موضوع است. نتايج بررسىهــاى خـاكشـناختى در

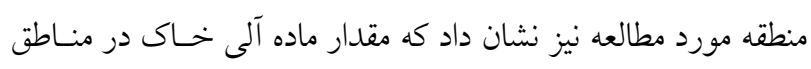

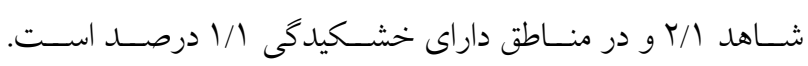
همجنــين مقـدار فسـفر خـاك بـهــور قابـل ملاحظـهاى در قطعـه

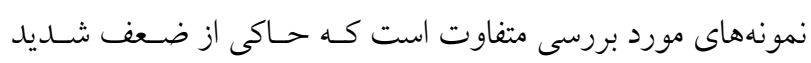

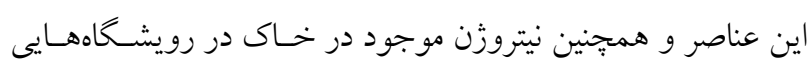

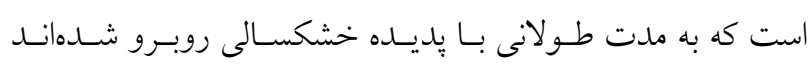

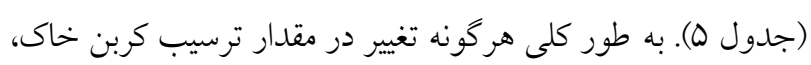

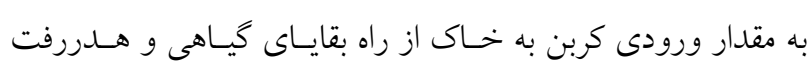

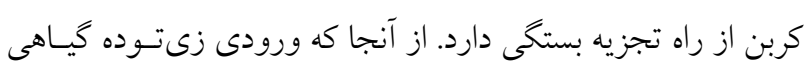
(مثل لاشريزه) به خاك متفاوت است، افزايش ميزان كـربن آلى و 
1. Bakhtiarvand Bakhtiari, S. 2011. Evaluation of methods for estimating the biomass of coniferous and deciduous trees in Mobarakeh Steel afforestation. MSc. Thesis. Faculty of Natural Resources and Land Sciences, Department of Natural Resources Engineering, Shahrekord University. $111 \mathrm{p}$.

2. Baldwin, L. and K. R. Richards. 2010. Institutional support for an International Forest Carbon Sequestration Agreement. Harward Project on Climate Agreements, Harvard Kennedy school, 33p.

3. Bigler, C. and T. T. Veblen. 2011. Changes in litter and dead wood loads following tree death beneath subalpine conifer species in northern Colorado. Canadian Journal of Forest Research 41: 331-340.

4. Campioli, M., H. Verbeeck, R. Lemeur and R. Samson. 2008. C allocation among fine roots, above and belowground wood in a deciduous forest and its implication to ecosystem $\mathrm{C}$ cycling: a modelling analysis. Biogeosciences Discuss 5: 3781-3823.

5. Chambers, J. Q., J. S. Santos, R. J. Ribeiro and N. Higuchi. 2001. Tree damage, allometric relationships, and aboveground net primary production in central Amazon forest. Forest Ecology and Management 152(1-3): 73-84.

6. Cienciala, E., J. Apltauer, Z. Exnerová and F. Tatarinov. 2008. Biomass functions applicable to oak trees grown in Central-European forestry. Journal of Forest Science 54(3): 109-120.

7. Clark, D. A., S. Brown, D. W. Kicklighter, J. Q. Chambers, , J. R. Tomlison and J. Ni. 2001. Measuring net primary production in forests: concepts and field methods. Ecological Applications 11: 356-370.

8. Dang, D. K. D, A. C. Patterson and L. R. Carrasco. 2019. An analysis of the spatial association between deforestation and agricultural field sizes in the tropics and subtropics. PLoS One 14(1): e0209918. https://doi.org/10.1371/journal.pone.0209918

9. Dinakaran, J. and N. S. R. Krishnayya. 2008. Variation in type of vegetation cover and heterogeneity of soil organic carbon in affecting sink capacity of tropical soils. Current Science 94(9): 1144-1150. (In Farsi)

10. FAO. 2006. Global forest resources assessment 2005: progress towards sustainable forest management. Food and Agriculture Organization of the United Nations, Rome.

11. FAO. 2010. Global forest resources assessment 2010. Food and Agriculture Organisation of the United Nations, Rome.

12. Gower, S. T., O. Krankina, R. J. Olson, M. Apps, S. Linder and C. Wang. 2001. Net primary production and carbon allocation patterns of boreal forest ecosystems. Ecological Applications 11: 1395-1411.

13. Huntington, T. G. 2003. Available water capacity and soil organic matter. pp. 1-5, In: R. Lal (ed.), Encyclopedia of Soil Science. Marcel Dekker, New York.

14. Houghton, R. A. and C. L. Goodale. 2004. Effects of land-use change on the carbon balance of terrestrial ecosystems. pp. 85-98, In: R. DeFries, G. Asner and R.A. Houghton (Eds.), Ecosystems and land use change. American Geophysical Union, North America.

15. Husch, B., T. W. Beers and J. A. Kershaw. 2003. Forest mensuration, $4^{\text {th }}$ Edition. John Wiley \& Sons Inc, USA. 443 $\mathrm{p}$.

16. IPCC. 2003. Good practices guidance for land use, land-use change and forestry. Edited by: Penman, J., M. Gytarsky, T. Hiraishi, T. Krug, D. Kruger, R. Pipatti, L. Buendia, K. Miwa, T. Ngara, K. Tanabe and F. Wagner. IGES, Institute for Global Environmental Strategies, Hayama, Japan, 590p.

17. Jordan, C. M., X. Hu, A. Arvesen, P. Kauppi and F. Cheubini. 2018. Contribution of ferest wood products to megative emissions: historical comparative analysis from 1960 to 2015 in Norway, Sweden and Finland. Carbon balance and management 13: 1-16.18. Iranmanesh, Y. 2013. Assessment on biomass estimation methods and carbon sequestration of Quercus brantii Lindl. in Chaharmahal \& Bakhtiari Forests, Ph.D. Thesis. Faculty of Natural Resources, Tarbiat Modares University, Noor. 107 p.

19. Iranmanesh, Y., Kh. Sagheb Talebi, H. Sohrabi, S. Gh. Jalali and S. M. Hosseini. 2014. Biomass and carbon stocks of Brant's oak (Quercus brantii Lindl.) in two vegetation forms in Lordegan, Chaharmahal \& Bakhtiari Forests. Iranian Journal of Forest and Poplar Research 22(4):749-762. (In Farsi)

20. Jordan, C. M, X. Hu, A. Arvesen, P. Kauppi and F. Cherubini. 2018. Contributionof ferest wood products to megative emissions: historical comparative analysis from 1960 to 2015 in Norway, Sweden and Finland. Carbon balance and management 13(12). https://doi.org/10.1186/s13021-018-0101-9

21- Khademi, A., S. Babaei and M. Mataji. 2010. The role of coppice oak stand in carbon storage and $\mathrm{CO}_{2}$ uptake (case 
study: Khalkhal, Iran). Iranian Journal of Forest and Poplar Research 18(2): 242-252. (In Farsi)

22. Kimble, J. M., C. W. Rice, D. Reed, S. Mooney, R. F Follett and R. Lal. 2007. Soil carbon management, economic, environmental and societal benefits, $1^{\text {st }}$ Edition. CRC Press, New York. 284 p.

23. Liu, M. Y., Q. R. Chang, Y. B. Qi, J. Liu and T. Chen. 2014. Aggregation and soil organic carbon fractions under different land uses on the tableland of the Loess Plateau of China. Catena 115: 19-28.

24. MacDicken, K. G. 1997. A guide to monitoring carbon storage in forestry and agroforestry projects. Winrock Internationl Institute for Agricultural Development, Forest Carbon Monitoring Program, USA. 87p.

25. Muukkonen, P. 2006. Forest inventory-based large-scale forest biomass and carbon budget assessment: new enhanced methods and use of remote sensing for verification, Ph.D. Thesis of Geography. University of Helsinki, Faculty of Science. $49 \mathrm{p}$.

26. Nosrati, K. 2011. The effect of land use and soil erosion on soil organic carbon and nitrogen stock. Environmental Erosion Research (3): 127-140. (In Farsi)

27. Olness, A. and D. Archer. 2005. Effect of organic carbon on available water in soil. Soil Science 170(2): 90-101.

28. Palik, B. J. and N. Pederson. 1996. Over story mortality and canopy disturbances in longleaf pine ecosystems. Canadian Journal of Forest Research 26: 2035-2047.

29. Parvaneh, E., V. Etemad, M. R. Marvie Mohajer, Gh. Zahedi Amiri and P. Attarod. 2016. The relationships between the rate of oak trees decline and forest types, soil characteristics and topographic conditions in Ghalaje Forests of Kermanshah, west of Iran. Iranian Journal of Forest 8(3): 263-275. (In Farsi)

30. Pato, M., A. Salehi, Q. Zahedi Amiri and A. Banj Shafiei. 2017. Estimating the amount of carbon storage in biomass of different land uses in Northern Zagros Forest. Iranian Journal of Forest 9(2): 159-170. (In Farsi)

31. Pourhashemi, M., M. Zandebasiri and P. Panahi. 2014. Structural characteristics of oak coppice stands of Marivan Forests. Journal of Plant Research 27(5): 766-776. (In Farsi)

32. Pourhashemi, M., H. Jahanbazi Goujani, J. Hoseinzade, S. K. Bordbar, Y. Iranmanesh and Y. Khodakaram. 2016. The history of oak decline in Zagros forests. Iran Nature 2(1): 30-37. (In Farsi)

33. Powers, J., S. Sollins, P. Harmon and J. A. Jones. 1999. Plant-pest interaction in time and space: a Douglas-fir bark beetle outbreak as a case study. Landscape Ecology 14: 105-120.

34. Rajan, K. 2010. Soil organic carbon- the most reliable indicator for monitoring land degradation by soil erosion. Current Science 99: 6-25.

35. Rozas, V. and L. Sampedro. 2013. Soil chemical properties and dieback of Quercus robur in Atlantic wet forests after a weather extreme. Plant and Soil 373: 673-685.

36. Rouvinen S., T. Kuuluvainen and J. Siitonen. 2002. Tree mortality in a Pinus sylvestris dominated boreal forest landscape in Vienansalo wilderness, eastern Fennoscandia. Silva Fennica 36(1): 127-145.

37. Saglant, B., O. Kucuki, E. Bilgili, D. Durmaz and I. Basal. 2008. Estimating fuel biomass of some shrub species (Maquis) in Turkey. Turkish Journal of Agriculture and Forestry 32: 349-356.

38. Sharma, K., A. Saiki, S. Goswami and M. Borthakur. 2020. Aboveground biomass estimation and carbon stock assessment along a topographical gradient in the forests of Manipur, Northeast India. Arabian Journal of Geosciences 13: 1-16.

39. Siitonen, J. 2002. Tree mortality in a Pinus sylvestris dominated boreal forest landscape in Vienansalo wilderness, eastern Fennoscandia. Silva Fennica 36(1): 127-145.

40. Wang, W. J., H. S. He, M. A. Spetich, S. R. Shifley, F. R. Thompson and J. S. Fraser. 2013. Modeling the effects of harvest alternatives on mitigating oak decline in a central hardwood forest landscape. PLoS ONE 8(6): e66713.

41. West, P. W. 2009. Tree and forest measurement. Springer Publisher, Germany. 190p.

42. Zahedi, Gh. and N. Zargham. 2018. Carbon sequestration in Terrestrial Ecosystems, $2^{\text {nd }}$ Edition. University of Tehran Academic Press, Tehran.

43. Zarafshar, M., M. Negahdarsaber, H. Jahanbazi Gojani, M. Pourhashemi, S. K. Bordbar, M. Matinizedeh and A. Abbasi. 2020. Dieback in pure stands of Brant`s oak (Quercus brantii Lindl.) in southern Zagros forests, Kohmareh Sorkhi region of Fars province. Iranian Journal of Forest 12(2): 291-303. (In Farsi) 


\title{
Comparison of Biomass and Carbon Stock on Above ground, Litter and Soil Between Healthy and declined Stands of Brant's Oak in Chaharmahal and Bakhtiari Province
}

\author{
Y. Iranmanesh ${ }^{1^{*}}$, M. Pourhashemi ${ }^{2}$, H. Jahanbazi ${ }^{1}$ and M. Talebi ${ }^{3}$
}

(Received: February 23-2021; Accepted: June 16-2021)

\begin{abstract}
In forest ecosystems, forest production, storage and carbon flow are calculated based on biomass measurements. The aim of this study was to compare the biomass and carbon stock of the above-ground, litter and soil in the oak decline and control plots in Chaharmahal and Bakhtiari province. Four one-hectare sample plots were selected in the healthy (control) and declined stands of oak. Then quantitative information of all trees were measured. Allometric equations were used to calculate the above-ground biomass and carbon stock. Ten microplots were established in each sample plot and all litters were collected. Wet and dry weights and carbon content of the litter samples were measured. To measure soil organic carbon, five soil samples were taken in each sample plot. The results showed that above-ground biomass in the control and decline sample plots were 31.4 and 15.8 tons/hectare respectively. Also, the average of the aboveground carbon stock in the control and decline plots were 15.1 and 7.7 tons/hectare, respectively. The mean of litter carbon in the control plots was $1584.1 \mathrm{~kg} / \mathrm{ha}$ and in the decline plots was $1148.6 \mathrm{~kg} / \mathrm{ha}$. The amount of carbon, nitrogen, phosphorus and soil moisture content showed a significant difference between the control and decline plots. The results of this study indicated significant changes in biomass, carbon stock and soil in declined stands of oak which may cause irreparable damage to the Zagros forest ecosystem, in the long term. This issue highlights the need for the attention of managers and decision makers of natural resources, regarding the provision of management solutions to control this phenomenon.
\end{abstract}

Keywords: Biomass, Carbon, Decline, Chaharmahal and Bakhtiari.

1. Assistant Prof., Research Division of Natural Resources, Chaharmahal and Bakhtiari Agricultural and Natural Resources Research and Education Center, AREEO, Shahrekord, I. R. Iran.

2. Associate Prof, Research Institute of Forests and Rangelands, Agricultural Research, Education and Extension Organization (AREEO), Tehran, I. R. Iran.

3. Senior Research Expert, Research Division of Natural Resources, Chaharmahal and Bakhtiari Agricultural and Natural Resources Research and Education Center, AREEO, Shahrekord, I. R. Iran

*: Corresponding Author, Email: y_iranmanesh@yahoo.com 